\title{
Behavioral Analysis of the Choice of Community-Based Formal Home Care, Informal Home Care and Nursing Home Care in Japan
}

\author{
Tetsuji Yamada a, Chia-Ching Chen ${ }^{\mathrm{b}}$, Tadashi Yamada ${ }^{\mathrm{c}}$, \\ Marianne Fahs ${ }^{\mathrm{d}}$ and Tetsuo Fukawa \\ ${ }^{a}$ Department of Economics, Rutgers University, the State University of New Jersey, Camden, New Jersey \\ 08102, U.S.A. \\ E-mail: tyamada@crab.rutgers.edu \\ ${ }^{\mathrm{b}}$ Department of Health and Behavior Studies, Teachers College, Columbia University, 525 West 120th \\ Street, New York, NY 10027-6625, U.S.A. \\ E-mail: cc2004@columbia.edu \\ ${ }^{\mathrm{c}}$ Graduate School of Humanities and Social Sciences, University of Tsukuba, 1-1-1 Tennodai, Tsukuba City, \\ Ibaraki Prefecture, 305-8573, Japan. \\ E-mail: tyamada@sk.tsukuba.ac.jp \\ ${ }^{\mathrm{d}}$ Graduate Program in Urban Public Health and Brookdale Center on Aging of Hunter College, School of \\ Health Sciences, Hunter College, City University of New York, 425 East 25 Street, New York, NY 10010, \\ U.S.A. \\ E-mail: mfahs@hunter.cuny.edu \\ ${ }^{\mathrm{e}}$ National Institute of Population and Social Security Research, Minister of Health, Labor and Welfare of \\ Japan, 2-2-3 Uchi-Saiwai Cho, Chiyoda-ku, Tokyo 100, Japan. \\ E-mail: fukawa@ipss.go.jp
}

The Japanese public long-term care insurance for the elderly is unequivocally a problem both for the health care system and as a social issue. The issues for the socially hospitalized and institutionalized are still unsolved due to a lack of family and community support. A central feature is to investigate the behavioral choices among elderly formal/informal home care and nursing home care. This study uses the General Survey on Actual Living Conditions of Elderly People as a natural experiment to analyze behavioral decision-making between the nursing home care and community-based formal/informal home care among the elderly. A logit model analysis that controls for socio-economic, demographic and physical/mental health influential factors was conducted. Developing community-based formal/informal home care would lead to economic gains. A provision of compensation to family health caregivers for their informal home care for the elderly is a key factor and a viable option.

The Geneva Papers (2006) 31, 600-632. doi:10.1057/palgrave.gpp.2510101

Keywords: formal/informal home care; nursing home care; Japan

\section{Introduction}

The Japanese public long-term care insurance (LTCI) program was launched in 2000 to curtail the dramatic increase in health care expenditures, as well as to meet the growing demand for long-term care due to the rapid growth of the elderly population. The insurance program was expected to give the elderly, defined as those aged 65 and over, and their family health caregivers, incentives to substitute institutional long-term 
care in hospitals and nursing homes with less costly community-based formal and informal home care. The program was considered to be extremely important not only to resolve the budget crisis but also to meet the health care needs of the elderly, who prefer to be cared for at home while physically impaired. However, the implemented community-based care program for the elderly is undoubtedly the problem of both the health care system and of society. Socially hospitalized and socially institutionalized issues are still unsolved due to a lack of family and community support. ${ }^{1}$

The central feature of the Japanese government's approach aims to reduce the number of socially hospitalized elderly patients that lead to a rapid increase in health care expenditures in an ageing society. In contrast to the government's efforts, the local groups put political pressure on the LTCI program and blame it for the inefficiency and insufficiency of long-term care services. A reform of the program for community-based formal home care of the elderly is imperative. There exist various types of long-term care, with different categories. Three main categories exist, which are: nursing home care (institutional long-term care services in nursing home), community-based formal home care (skilled and semi-skilled home care services at home) and informal home care (provided at home by family members). However, within these categories there exist sub-categories, especially regarding community based formal home care, as shown later in Tables 1 and 2.

There have been a number of papers showing that the interactions between nursing home care and community-based formal home care depend on the Medicaid benefits, ${ }^{2}$ the quality of nursing home care and the respective public reimbursement program. ${ }^{3}$ (The Appendix summarizes and reviews these results, highlighting the major characteristics of each study.) Other studies ${ }^{4}$ support the substitution of communitybased formal/informal care for nursing home care, while some scholars emphasize the role of the spouse and the children. ${ }^{5}$ On the other hand, Moscovice et al. ${ }^{6}$ and Paulus et $a l .^{7}$ underscore a lack of substitution between community-based formal home care and informal home care. Bauer, ${ }^{8}$ Portrait et al. ${ }^{9}$ Lakdawalla and Schoeni, ${ }^{10}$ Geerlings et al., ${ }^{11}$ and Puts et al. ${ }^{12}$ ascertained that nursing home entry and community-based formal home care would be affected more by factors related to chronic diseases and functional limitation, rather than by the support network for the elderly.

There have also been quantities of studies that have evaluated long-term care in Japan. Some ${ }^{13}$ have reported that the prevalence of long-term care depends on health

\footnotetext{
${ }^{1}$ Arai et al. (2004); Oura et al. (2006).

${ }^{2}$ Swan and Benjamin (1990); Ettner (1994); Grabowski and Gruber (2005).

${ }^{3}$ Grabowski (2001); Grabowski et al. (2004); Mor et al. (2004).

${ }^{4}$ Greene (1983); Kemper (1992); Greene et al. (1993); Stern (1995); and Charles and Sevak (2005).

${ }^{5}$ Lakdawalla and Philipson (1999); Mellor (2001); Himes et al. (2001); and Gaugler et al. (2004).

${ }^{6}$ Moscovice et al. (1988).

${ }^{7}$ Paulus et al. (2005).

${ }^{8}$ Bauer (1996).

${ }^{9}$ Portrait et al. (2000).

${ }^{10}$ Lakdawalla and Schoeni (2003).

11 Geerlings et al. (2005).

12 Puts et al. (2005).

${ }^{13}$ Kurimori et al. (2006); Nishiwaki et al. (2005).
} 
602

characteristics, including the dependence of activities for daily living; others ${ }^{14}$ highlighted the role of family caregivers and the burden of taking care of their impaired elderly. Issues concerning hospitals, health care facilities and nursing homes for the elderly have been discussed in many aspects regarding reimbursement programs, that is, fee-for-service system for lengthy hospitalization. ${ }^{15}$ This means over-medication and excessive ordering of laboratory tests are performed for the elderly in the hospitals. ${ }^{16}$ Kimura $^{17}$ suggested a less expensive community-based formal home care, compared to the more expensive hospital care. Furthermore, Sato et $a l .{ }^{18}$ affirmed that the interim subsidy for low-income beneficiaries alleviates economic burdens and induces the substitution of home help services. Reimbursement price, ${ }^{19}$ the annual real wage rate, ${ }^{20}$ and price elasticity ${ }^{21}$ are also underlined to facilitate less expensive community-based formal home care over hospital-based care.

Few studies have attempted to identify factors related to the interactions among nursing home care, community-based formal home care, and informal home care in Japan. Regarding the formulation of a policy, which will contain the rising national health care expenditure, the study considers it imperative to clarify these interactions by using the micro-data on the elderly. While acknowledging the previous research on long-term care, the present study pays attention to the decision-making behaviors of the elderly in order to understand determinants of different long-term care services and possible substitution among the services, using the micro data on the Japanese elderly, aged 65 and over. An examination of the socio-economic and demographic characteristics of the elderly, similar to those of the U.S. studies, but drawn from a different set of national characteristics, reveals a new insight into the literature, thereby filling the literature gap. Our findings provide a better understanding of the real needs of the elderly and clarify behavioral decision-making among the elderly who are physically impaired.

The study addresses the concern with three basic questions that are related to longterm health care policy. (1) What are the basic behavioral determinants of the elderly when making choices for nursing home care, community-based formal home care, and informal home care? (2) Do substitutions among the different long-term care programs exist? If so, to what extent do they exist? (3) Does an expansion of community-based formal home care lead to a growth of informal home care by family caregivers, as the national government expects under the current long-term care insurance program? The results of these investigations are important in coping with the problem of rapidly growing public health care expenditures within the ageing society in Japan.

The paper is organized as follows. Japan's long-term care for the elderly is briefly discussed. Then the analytical framework presents a simple model to describe elderly

\footnotetext{
${ }^{14}$ Iwamoto (2000); Arai (2004); and Arai et al. (2004).

${ }^{15}$ Ogura and Oishi (1994); Horiguchi et al. (2004).

${ }^{16}$ Ikegami et al. (1994).

${ }^{17}$ Kimura (1996).

${ }^{18}$ Sato et al. (2006).

${ }^{19}$ Kobayashi and Reich (1993).

${ }^{20}$ Chuma et al. (1994).

${ }^{21}$ Ohkusa (2000).
} 
behavioral decision-making among nursing home care with community-based formal/ informal home care, and description of data and variables. Next, the empirical results are presented. The final section presents the conclusion, as well as the policy implications.

\section{Japan's long-term care for the elderly}

A large number of the Japanese elderly are long-term care inpatients in acute care hospitals. There are two explanations for this. First, the national health insurance system allows for lengthy hospitalization at a minimum cost to the patients; second, there has been a shortage of public institutional long-term health care facilities for the elderly. Consequently, the increasing demand for long-term care due to the rapid growth of the elderly population has forced the Japanese government to develop more nursing homes and community-based formal home care services.

There are four major types of public institutional long-term care services, all of which have different functions and purposes: (1) the long-term care health facility for the elderly (kaigo rhojin-hoken sisetsu in Japanese); (2) the long-term care welfare facility for the elderly (kaigo rhojin-fukushi shisetsu in Japanese); (3) the long-term care for the elderly (keihi-rhojin home); and (4) the community-based formal home services. The long-term care health facility provides institutional care for the elderly during the transition from hospital to home care. Likewise, the long-term care welfare facility also provides institutional care services for the elderly who need constant care but do not live with any informal caregivers at home. Detailed classifications among these public institutional long-term care facilities are shown in Table 1. The national and local governments subsidize the operating costs for these long-term care services. The elderly in the long-term care facilities (i.e., the aforementioned types 1, 2, and 3) are responsible for all daily expenses, and the monthly expenses are determined according to either their annual income or the actual expenses of their daily activities. To meet the needs of the elderly, the community-based formal home care services also offer doctor visits, nurse visits ( 9,900 nurse stations), home help visits ( 0.35 million service persons), bathing, meals, laundry services, cleaning, equipment provision, and counseling (in 2004). The public services that were available for community-based formal home care (i.e., the aforementioned type 4) in 2004 were community-based dayservice centers $(26,000$ centers) and short-stay facilities for the elderly (96,000 beds). The day-service centers offer services such as meals, bathing, training and practices of daily activities, guidance, and caregiver classes. The short-stay center for the elderly is a facility for care, not for cure, intended to lessen the burden of family caregivers (e.g., a maximum 7-day stay with a conditional extension). However, in reality due to insufficient provisions of long-term care and community-based formal home care, the elderly are not always able to receive the services at their discretion. The physically impaired elderly often wait a few years at home before being admitted to a long-term care welfare facility.

The long-term care insurance program is under the jurisdiction of the municipal governments. There are two groups of beneficiaries: the elderly aged 65 and over (the first insured); and people aged 40-64 years, suffering from senility (the second insured). The former qualify for formal home care services and long-term care at 
Table 1 Long-term care and their characteristics

\begin{tabular}{|c|c|c|c|c|}
\hline $\begin{array}{l}\text { Types of Long-term } \\
\text { Care Program }\end{array}$ & $\begin{array}{l}\text { Long-term care health facility } \\
\text { for the elderly (kaigo-rhojin } \\
\text { hoken sisetsu, in Japanese) }\end{array}$ & $\begin{array}{l}\text { Long-term care welfare facility } \\
\text { for the elderly (kaigo-rhojin } \\
\text { fukushi shisetsu in Japanese) }\end{array}$ & $\begin{array}{l}\text { Long-term care home for the } \\
\text { elderly (keihi-rhojin home in } \\
\text { Japanese) } \\
\text { - Type A Home } \\
\text { - Type B Home } \\
\text { - Care House }\end{array}$ & $\begin{array}{l}\text { Community-based formal } \\
\text { home care services at home }\end{array}$ \\
\hline Functions & $\begin{array}{l}\text { To care for the frail or } \\
\text { bedridden elderly aged } 65 \text { or } \\
\text { over for convalescence } \\
\text { following hospitalization }\end{array}$ & $\begin{array}{l}\text { To care for the bedridden } \\
\text { elderly aged } 65 \text { or over } \\
\text { - A substitute place to live in } \\
\text { because of difficulties in } \\
\text { being taken care of at home }\end{array}$ & $\begin{array}{l}\text { To care for the elderly aged } \\
65 \text { or over } \\
\text { The elderly with very low } \\
\text { income } \\
\text { - Physical difficulties at home } \\
\text { because of their } \\
\text { environment or housing } \\
\text { circumstances }\end{array}$ & $\begin{array}{l}\text { - Home-based care for the } \\
\text { elderly aged } 65 \text { or over, who } \\
\text { have difficulties at home } \\
\text { because of their } \\
\text { environment or who need } \\
\text { home services }\end{array}$ \\
\hline Types of services & $\begin{array}{l}\text { - Medical services } \\
\text { - Rehabilitation after } \\
\text { bedridden conditions } \\
\text { - Training of daily activities } \\
\text { - Other basic services } \\
\text { necessary for daily activities }\end{array}$ & $\begin{array}{l}\text { - Healthcare services } \\
\text { - Rehabilitation after } \\
\text { bedridden conditions } \\
\text { - Other basic services } \\
\text { necessary for daily activities }\end{array}$ & $\begin{array}{l}\text { - Meals (preparing and } \\
\text { cooking own meals is } \\
\text { required at Type B home) } \\
\text { - Bathing } \\
\text { - Other basic services } \\
\text { necessary for daily activities }\end{array}$ & $\begin{array}{l}\text { Formal home services } \\
\text { provide services such as } \\
\text { meals, bathing, toilet, } \\
\text { training and practice of } \\
\text { daily activities, guidance, } \\
\text { laundry services and } \\
\text { caregiver classes }\end{array}$ \\
\hline $\begin{array}{l}\text { Number of capacity } \\
\text { (beds) }\end{array}$ & $\begin{array}{l}\text { - } 0.297 \text { million patients or } \\
\text { residents (in 2004) }\end{array}$ & $\begin{array}{l}0.36 \text { million patients or } \\
\text { residents (in 2004) }\end{array}$ & $\begin{array}{l}-0.105 \text { million patients or } \\
\text { residents (in 2004) }\end{array}$ & $\begin{array}{l}0.35 \text { million formal home } \\
\text { visits capacity (in 2004) }\end{array}$ \\
\hline $\begin{array}{l}\text { Monthly subsidy } \\
\text { costs per elderly }\end{array}$ & $\begin{array}{ll}\text { - } & \text { Level I: } \$ 2,490 \\
\text { - } & \text { Level II: } \$ 2,640 \\
\text { - } & \text { Level III: } \$ 2,800 \\
\text { - } & \text { Level IV: } \$ 2,960 \\
\text { - } & \text { Level V: } \$ 3130 \text { (in 2004) }\end{array}$ & $\begin{array}{ll}\text { - } & \text { Level I: } \$ 2,060 \\
\text { - Level II: } \$ 2,270 \\
\text { - Level III: } \$ 2,490 \\
\text { - Level IV: } \$ 2,700 \\
\text { - Level V: } \$ 2,920 \text { (in 2004) }\end{array}$ & $\begin{array}{l}\text { - Type A Home } \\
\$ 1,740 \text { at a } 50 \text {-bed home } \\
\$ 1,200 \text { at a } 80 \text {-bed home } \\
\$ 1,100 \text { at a } 100 \text {-bed home } \\
\text { - Type B Home } \$ 439 \\
\text { - Care House } \$ 1,197 \text { (in } 2000 \text { ) }\end{array}$ & $\begin{array}{l}\text { A }(\$ 0 / \mathrm{h})-\mathrm{G}(\$ 9.1 / \mathrm{h}) \text { based } \\
\text { on income level before } 2000 \\
\text { Level } \mathrm{I}(\$ 165)-\mathrm{V}(\$ 358.3) \\
\text { per month with the public } \\
\text { long-term care insurance }\end{array}$ \\
\hline
\end{tabular}


Table 1 (continued)

\begin{tabular}{|c|c|c|c|c|}
\hline $\begin{array}{l}\text { Financial sharing of } \\
\text { costs }\end{array}$ & $\begin{array}{l}\text { - Insured }(65+): 18 \text { per cent } \\
\text { - Insured }(40-60): 32 \text { per cent } \\
\text { - National Gov't: } 25 \text { per cent } \\
\text { - Prefectural Government: } \\
12.5 \text { per cent } \\
\text { - Municipal Government: } \\
12.5 \text { per cent }\end{array}$ & $\begin{array}{l}\text { - Insured }(65+): 18 \text { per cent } \\
\text { - Insured }(40-60): 32 \text { per cent } \\
\text { - National Government: } \\
25 \text { per cent } \\
\text { - Prefectural Govrenment: } \\
12.5 \text { per cent } \\
\text { - Municipal Government: } \\
12.5 \text { per cent }\end{array}$ & $\begin{array}{l}\text { - Insured }(65+) \text { : } \\
18 \text { per cent } \\
\text { - Insured }(40-60) \text { : } \\
32 \text { per cent } \\
\text { - National Government: } 25 \\
\text { per cent } \\
\text { - Prefectural Government: } \\
12.5 \text { per cent } \\
\text { - Municipal Government: } \\
12.5 \text { per cent }\end{array}$ & $\begin{array}{l}\text { - Insured }(65+) \text { : } \\
18 \text { per cent } \\
\text { - Insured }(40-64) \text { : } \\
32 \text { per cent } \\
\text { - National Government: } 25 \\
\text { per cent } \\
\text { - Prefectural Government: } \\
12.5 \text { per cent } \\
\text { - Municipal Government: } \\
12.5 \text { per cent }\end{array}$ \\
\hline $\begin{array}{l}\text { Personal charges per } \\
\text { month }\end{array}$ & $\begin{array}{l}\text { - To be determined according } \\
\text { to the elderly annual income } \\
\text { (10 per cent of costs } \\
\text { with maximum limit plus } \\
\text { meals) }\end{array}$ & $\begin{array}{l}\text { To be determined according } \\
\text { to the elderly annual income } \\
\text { ( } 10 \text { per cent of costs } \\
\text { with maximum limit plus } \\
\text { meals) }\end{array}$ & $\begin{array}{l}\text { - Type A and Care House: } \\
\text { to be determined according } \\
\text { to the elderly annual } \\
\text { income } \\
\text { - Type B: total costs }\end{array}$ & $\begin{array}{l}\text { - To be determined according } \\
\text { to the elderly annual income } \\
\text { ( } 10 \text { per cent of costs with } \\
\text { maximum limit) }\end{array}$ \\
\hline
\end{tabular}

Notes: Community-based formal home care includes community-based day-service and short-stay facility centers (see the second paragraph in section on Japan's Long-term Care for the Elderly). This table does not include the long-term care medical facilities that are rather related to hospital characteristics.

Sources: Journal of Health and Welfare Statistics, 2004, Ministry of Health, Labor and Welfare of Japan; Kousei Roudo Hakusho (in Japanese), 2001, Ministry of Health, Labor and Welfare of Japan; and Kaigo Hoken no Tebiki (in Japanese), 2000, Gyousei; Roujin no Hoken Iryo to Fukushi (in Japanese), 1995, Ministry of Health, Labor and Welfare of Japan. 
nursing homes (i.e., the long-term care health facility for the elderly and the long-term care welfare facility for the elderly) and hospitals. The latter can receive these services only when their requirements (e.g., assistance for bathing and clothing with basic activities of daily life) are screened and approved by a long-term care approval board in the municipal government. Although the health care services of the long-term care insurance program generally fall under the jurisdiction of the local municipal or prefectural governments, all of them are authorized and supervised by the national government. Regarding the involvement in financing, the monetary burden of the long-term care insurance program is shared in an amount of 12.5 per cent by the municipal governments; in an amount of 12.5 per cent by the prefectural governments; in an amount of 25 per cent by the national government, and 50 per cent by the insurer. The share by the insurer is contributed by the first insured (18 per cent) and by the second insured (32 per cent), respectively. ${ }^{22}$

Before the long-term care insurance was launched in 2000, long-term care for the elderly was provided as health care services based on the government measures for public health. Following the introduction of long-term insurance focusing on longterm care in 2000 , the elderly (the first insured) are required to pay premiums for the insurance to which the people aged 40 and older (the second insured) also contribute, and in turn the benefits are available mainly for the elderly.

Each municipality government makes a long-term care insurance service plan based on identified local needs which have been financed by the public funds through municipal governments in an amount 12.5 per cent, by prefectural governments in an amount of 12.5 per cent, by the national government in an amount of 25 per cent, by the first insured (about 18 per cent), and the second insured (about 32 per cent) since $2000 .^{23}$ In addition to each prefectural plan for a long-term care insurance service support beyond municipal boundaries, each municipal government takes an independent approach to provide well-balanced long-term care by considering the financial burden on the insured and the municipal government. The premium is

${ }^{22}$ For example, the amount of the subsidy for the long-term care welfare facility for the elderly, per person, is $\$ 2,060$ in severity in degree I, \$2,270 in degree II, \$2,490 in degree III, \$2,700 in degree IV, and \$2,920 in degree V (see Table 1). These subsidy costs are shared and paid for by the insured, aged 65 and over (18 per cent), the insured, aged 40-60 (32 per cent), national government ( 25 per cent), prefecture government (12.5 per cent), and municipal government (12.5 per cent). For the out-of-pocket expenses, the program sets limits on the amount that the elderly pay. The maximum monthly expenses cost $\$ 372$ for an elderly person; $\$ 246$ for an elderly person with a low income; and $\$ 150$ for an elderly person aged 70 and over. Similarly, the costs of meals per month on average are \$228 for an elderly person; \$150 for an elderly person with a low income; and $\$ 90$ for an elderly person aged 70 and over (Kokumin Eisei no Doukou (1997 and 2004), Health and Welfare Statistical Association, Tokyo). All dollar values in this paper are calculated based on the exchange rate of $\$ 1=100$ yen, for brevity. We note that, according to OECD HEALTH DATA 2005, per capita health expenditures incorporate the purchasing power parity (PPP), $\$ 1=124$ yen, in calculation. However, ours use $\$ 1=100$ yen for two reasons: first, the dollar value in PPP seems to underestimate the reality in Japan because of 0-1 per cent inflation rate; and second, the current exchange rate is $\$ 1=110$ yen (2005) in dollar value, and can be easily translated into the PPP value.

${ }^{23}$ Kokumin Fukushi no Doukou (2000 and 2004), Health and Welfare Statistical Association, Tokyo. Reevaluation of the Japanese Public Long-term Care Insurance Program (Kaigohoken Seido no Minaoshi ni Tsuite in Japanese); Report of the Social Security Committee (2004). 
determined according to the elderly annual income, namely his or her social security retirement benefit. ${ }^{24}$ Furthermore, the premium also depends on the total quantity of care utilization, and the ratio of the elderly to the rest of the population, aged 65 and less, in the municipality. Then, the adjustment is made by the government, and the municipal government receives the subsidy from the national government. The premium is based on the benefit approach, which depends on monthly retirement benefit amounts, and is automatically deducted from the social security benefits. The monthly premium differs slightly from the above-mentioned standard premium according to an elderly retirement benefit level.

\section{Analytical framework}

In this section, the empirical framework is discussed, including the theoretical background of health-related issues and the specification of models, followed by an explanation of data characteristics. An assessment of the health characteristics is discussed regarding subjective and objective measures. This empirical study employs objective measures of health characteristics for evaluating elderly behavioral decisionmaking.

\section{Statistical model}

A typical elderly person " $i$ " is assumed to be a utility maximizer and enjoys his or her healthy time. The individual's utility, $U_{i}$, is assumed to be a function of healthy time $L_{i}$, informal home care $Q_{i}$, and a vector of consumption goods $Z_{i}$, as follows:

$$
\begin{aligned}
& U_{i}=U\left(L_{i}, Q_{i}, Z_{i}\right) \\
& u_{i}^{\prime}=\partial U_{i} / \partial X_{i}>0, u_{i}^{\prime \prime}=\partial u_{i}^{\prime} / \partial X_{i}<0, \text { for } X_{i}=L_{i}, Q_{i}, \text { and } Z_{i} .
\end{aligned}
$$

Concerning the healthy time, we assume $\mathrm{L}_{\mathrm{i}}$ is determined by publicly provided professional care services:

$$
\begin{aligned}
& L_{i}=f\left(S_{i, N H}, S_{i, F H C} ; E N_{i}\right) \\
& f_{N H}^{\prime}\left(=\partial L_{i} / \partial S_{i, N H}\right)>0, f_{F H C}^{\prime}>0, f_{E N}^{\prime}>0, f_{N H}^{\prime \prime}\left(=\partial f_{N H}^{\prime} / \partial S_{i, N H}\right)<0, \\
& f_{F H C}^{\prime \prime}<0, f_{E N}^{\prime \prime}<0, \text { and } \partial S_{i, N H} / \partial S_{i, F H C}>0 \text { or }<0,
\end{aligned}
$$

\footnotetext{
${ }^{24}$ The standard monthly premium for the care insurance program is approximately $\$ 30$ per elderly person, aged 65 and over. The standard premium is determined by the following formula: (1/8 of annual care expenses within the municipality $\times 0.17$ )/the total number of the elderly aged 65 and over living in the municipality. The municipal government directly collects the premiums from the elderly. In addition to the monthly premium, care-service recipients must also pay 10 per cent of the basic cost of care services out of their own pockets. The 10 per cent co-payment is capped and is based on the amount of the income level in order to lighten the financial burden of the elderly. The service recipient, in addition to the basic 10 per cent of the cost incurred for services, must pay meal expenses. The source comes from the Kokumin Fukushi no Doukou (2005), Health and Welfare Statistical Association, Tokyo.
} 
where $S_{i, N H}$ stands for nursing home care as a health input; $S_{i, F H C}$ stands for community-based formal home care; and $E N_{i}$ stands for health characteristics of the elderly person, which affect his/her daily living activities. ${ }^{25}$ The relationship between nursing home care and community-based formal home care $\left(\partial S_{i, N H} / \partial S_{i, F H C}\right)$ depends on whether they are complements or substitutes of each other.

With respect to informal home care, $Q_{i}$ is considered as a joint product of the elderly and family member(s). The production of $Q_{i}$ is assumed to be weakly separable from that of $L_{i}$ in the utility function. Finally, $Q_{i}$ is a function of the caregiver's informal home care services provided to an elderly, $S_{I H C}$, and a vector of health-promoting consumption goods, $H_{i}$ :

$$
\begin{gathered}
Q_{i}=\Psi\left(S_{I H C}(T), H_{i}\right) \\
H_{i} \in Z_{i} \quad \text { and } \quad \Psi_{i}^{\prime}\left(=\partial Q_{i} / \partial Y_{i}\right)>0, \quad \Psi_{i}^{\prime \prime}\left(=\partial \Psi_{i}^{\prime} / \partial Y_{i}\right)<0,
\end{gathered}
$$

where $Y_{i}$ represents either $S_{I H C}$ or $H_{i}$, and $T$ denotes time spent caring for the elderly person by him/herself together with a family caregiver. Thus, an increase in $T$ implies a reduction in potential time available for the caregiver's market, as well as other nonmarket activities.

The budget constraint for the elderly person is expressed in terms of the shadow prices of healthy time, the joint product, and a vector of the prices of consumption goods (for brevity, we omit the subscript " $i$ " to represent an individual elderly in subsequent arguments):

$$
B=L\left(S_{N H}, S_{F H C} ; E N\right) \cdot P_{L}+Q\left(S_{I H C}(T), H\right) \cdot P_{Q}+Z \cdot P_{Z} .
$$

In the above budget constraint, $P_{L}$ is a shadow price of healthy time and depends on the attributes of $S_{N H}, S_{F H C}$ and EN. $P_{Q}$ is also a shadow price of the joint product of informal home care, reflecting attributes of $S_{I H C}$, and the prices of health promoting consumption goods $H . P_{Z}$ is a vector of the prices of consumption goods $Z$.

In this model, we assume the elderly person's utility maximization function to be a separable additive function subject to the budget constraint (4):

$$
\begin{aligned}
U(L, Q, Z)= & \max _{L, Q, Z}\left[U \left\{L\left(S_{N H}, S_{F H C} ; E N\right)\right.\right. \\
& \left.+Q\left(S_{I H C}(T), H\right)+Z\right\}: L\left(S_{N H}, S_{F H C} ; E N\right) \cdot \mathrm{P}_{\mathrm{L}} \\
& \left.+Q\left(S_{I H C}(T), H\right) \cdot P_{Q}+Z \cdot P_{Z} \leq B\right],
\end{aligned}
$$

where the above additive nature implies that the preference is implicitly separable. ${ }^{26}$ From the first-order conditions of maximization, with some modification, we can obtain:

$$
u_{L, S(N H)}^{\prime}=\left(P_{L} / P_{Q}\right)\left(u_{Q, S(I H C)}^{\prime}+u_{Q, H}^{\prime}\right)-u_{L, S(F H C)}^{\prime}-u_{L, E N}^{\prime}
$$

\footnotetext{
${ }^{25}$ Kurimori et al. (2006); Nishiwaki et al. (2005).

${ }^{26}$ Deaton and Muellbauer (1984).
} 
where $\mathrm{u}_{\mathrm{L}, \mathrm{S}(\mathrm{NH})}^{\prime}\left[=(\partial \mathrm{U} / \partial \mathrm{L})\left(\partial \mathrm{L} / \partial \mathrm{S}_{\mathrm{NH}}\right)\right]>0, \mathrm{u}_{\mathrm{Q}, \mathrm{S}(\mathrm{IHC})}^{\prime}\left[=(\partial \mathrm{U} / \partial \mathrm{Q})\left(\partial \mathrm{Q} / \partial \mathrm{S}_{\mathrm{IHC}}\right)\right]>0, \mathrm{u}_{\mathrm{Q}, \mathrm{H}}^{\prime}$ $>0, \mathrm{u}_{\mathrm{L}, \mathrm{S}(\mathrm{FHC})}^{\prime}>0$, and $\mathrm{u}_{\mathrm{L}, \mathrm{EN}}^{\prime}>0 .{ }^{27}$ Equation (6) indicates that the marginal utility of healthy time, with respect to nursing home care, is equal to the ratio of the shadow prices $\left(P_{L} / P_{Q}\right)$, multiplied by the marginal utilities of the joint product with respect to informal home care and with respect to health promoting consumption goods, minus the marginal utility of healthy time with respect to community-based formal home care, minus the marginal utility of healthy time with respect to the elderly person's health characteristics.

In equation (6), an increase in the opportunity costs of informal home care provided by a family caregiver reduces the price ratio $P_{L} / P_{Q}$ and discourages informal care time $T$. However, a reduction in $T$ increases $u_{Q, S(I H C)}^{\prime}$, and there is also an input-substitution of $H$ for $S_{I H C}(T)$ in the joint production of $Q$. Moreover, $L\left(S_{N H}\right.$, $\left.S_{F H C} ; E N\right)$ might be substituted for $Q$. Therefore, an increase in the opportunity costs will give the elderly person (and the family caregiver) an incentive to substitute nursing home care and community-based formal home care for informal home care. In a similar way, we can also expect a substitution between $L$ and $Q$ (or that between $S_{N H}$ and $S_{F H C}$ ) to respond to a change in the shadow price of the elderly person's healthy time $P_{L}$. The key implication here is the interdependency among nursing home care, community-based formal home care and informal home care.

Concerning the variables $S_{N H}, S_{F H C}$ and $S_{I H C}$, in the General Survey on Actual Living Conditions of Elderly People 1990 (hereafter referred to as General Survey) which focuses on behavioral decision-making of nursing home care, community-based formal home care, and informal home care among the elderly for this analysis (see the next section on data and variables), the question of interest for the study is: "When you become bedridden, as a means of long-term care, would you prefer a nursing home or a formal home care facility; or are you indifferent between them?' Hence, the observed values for $S_{N H}$ and $S_{F H C}$ are discrete because an elderly person in the sample prefers either nursing home care or community-based formal home care. The General Survey, however, had no questions related to informal home care to the elderly, that is, the number of informal home care hours per day that family caregivers provide. The sample for the estimation of informal home care hours basically consists of the elderly respondents having bad health conditions. We use the total hours of basic daily activities by the elderly with bad health conditions. The activities are eating, bathing, dressing, toileting, transferring, and bowel and bladder continence, excluding other hours spent on sleeping, associating, resting, leisure, etc. We assume that the activities are assisted by a family caregiver. ${ }^{28}$

${ }^{27}$ For the utility maximization with respect to $L$ and $Q$, we obtain: $\partial \xi / \partial L=\xi_{L}=u_{L, S(N H)}^{\prime}+u_{L, S(F H C)}^{\prime}+$ $u_{L, E N}^{\prime}-\lambda \cdot P_{L}=0 ;$ and, $\partial \xi / \partial Q=\xi_{Q}=u_{Q, S(I H C)}^{\prime}+u_{Q, H}^{\prime} \lambda \cdot P_{Q}=0$.

${ }^{28}$ Moscovice et al. (1988); Kemper (1992); Iwamoto (2000); Lakdawalla and Schoeni (2003); Gaugler et al. (2004). As for the measurement of informal home care, Moscovice et al. (1988) use total hours spent per quarter by the informal care network, while Kemper (1992) employs informal visiting hours by friends, neighbours, and family members. According to the General Survey, 80 per cent of bedridden elderly people are taken care of by their family members at least for the last 6 months before death, 16 per cent of them by visitors from the local health agency, and the final 4 per cent by relatives, who do not live together with the elderly. In general, when the spouse and the bedridden elderly person are living together and active, the spouse is most likely to be the primary caregiver (Iwamoto (2000); Lakdawalla and Schoeni (2003); Arai et al. (2004)). 
610

The study is concerned with the specifications of our models because of the endogeneity problems of nursing homes, community-based formal home care and informal home care; for this, the study used two ways for testing endogeneity. First, the F-values of the Hausman-Wu test were examined by following Hausman ${ }^{29}$ and Nakamura and Nakamura. ${ }^{30}$ The study applied the Hausman-Wu test for these specifications and accepted the null hypothesis that there is no simultaneity between the variables in question. ${ }^{31}$ Second, the study used the $t$-test method described in Gujarati $^{32}$ and Wooldridge. ${ }^{33}$ The results also show that there is no endogeneity of the variables. Therefore, a simultaneous-equation approach is not used for the models in this paper. ${ }^{34}$

In order to simplify the analysis, the study used a logit model (LOGIT) for nursing home care $S_{N H}$ and community-based formal home care $S_{F H C}$, and an ordinary least squares model (OLS) for informal home care $S_{I H C}{ }^{35}$ In the probability estimation of choosing formal home care services, the questionnaire in the General Survey is, "When you become bedridden, which would you choose among the community-based formal home care services (i.e., community-based day-service and short-stay facility centers, doctor visits, nurse visits, home help visits, bathing, meals, etc.)? Name three at most." We group the various formal home care services into day\&short center, skilled home care and semi-skilled home care, as shown in Table 2. Skilled home care consists of medically oriented community-based formal home care services such as doctor visits and nurse visits. Semi-skilled home care includes nonmedical services such as home help visits, bathing, and meals services. ${ }^{36}$ Therefore, the logit model of this study seems less hazardous than a multinomial logit model since the latter must choose an arbitrary combination of various formal home care services.

${ }^{29}$ Hausman (1978).

${ }^{30}$ Nakamura and Nakamura (1981).

${ }^{31}$ The F-value on the variable of the estimated community-based day-services and short-stay facility centers (i.e., day\&short center), obtained from its reduced form equation, is 0.176 in the nursing home care equation; the F-value on the variable of the estimated nursing home care obtained from its reduced form, is 0.336 in the day\&short center equation; and the F-values on the variables of the estimated formal home care and informal home care obtained from their reduced forms are 0.180 and 0.092 , respectively, in the formal home care service equation.

32 Gujarati (1999).

${ }^{33}$ Wooldridge (2003).

${ }^{34}$ The estimated coefficient on the estimated residuals, obtained from the reduced form equation of day\&short center, is $0.134(t=0.595)$ in the nursing home equation (related to the Nursing Home Care equation in Table 3a). The estimated coefficient on the estimated residuals, obtained from the reduced form equation of nursing home care, is $0.357(t=0.820)$ in the day\&short center equation (related to the day\&short center equation in Table 3a). Finally, the estimated coefficients on the residuals of the day\&short center and informal home care are, respectively, $-0.163(t=-0.602)$ and $-0.035(t=-0.431)$ in the formal home care equation (related to the Formal Home Care equation in Table $3 \mathrm{~b}$ ).

${ }^{35}$ A nursing home care, $S_{N H}$, means an institutional care in Japan, such as a health facility for the elderly, a special nursing home for the elderly, a nursing home for the elderly, and a home for the elderly.

${ }^{36}$ Previous research uses different measurements of formal home care: hours of caregiving per day (Arai et al. (2004)), paid activity-days of care received per week (Ettner (1994)), hours per week of in-home assistance with medical treatment (Kemper (1992)), total expenditures for Alternative Care Grants Program per quarter (Moscovice et al. (1988); Sato et al. (2006)), and the number of paid home care visits per week (Coughlin et al. (1992)). 
Accordingly, we separately estimate the following simple models.

LOGIT $: N H=\Phi_{1}(F H C, I H C, A V F, E C, E N, S D)$,

LOGIT $: F H C=\Phi_{2}(N H, I H C, A V F, E C, E N, S D)$,

and

$$
\text { OLS :IHC }=\Phi_{3}(N H, F H C, A V F, E C, E N, S D),
$$

where NH stands for nursing home care, FHC for community-based formal home care, and IHC for informal home care. AVF and EC represent availability of family assistance, and a vector of economic factors, respectively. EN represents the health characteristics of an elderly individual. SD indicates a vector of socio-demographic factors of the individual: gender, age, community associations, etc. Although many aspects of public nursing homes across the country have been assimilated by the national government, the quality of nursing home care services most likely varies in different places. As no information is available to correct those deficiencies, the study is unable to mitigate the possible bias(es). In addition, the study does not impose supply constraints in the regression analysis, because the fees at public nursing homes and community-based formal home care services are fixed across the country, but vary according to the service recipient's income.

\section{Data and variables}

This study uses the General Survey (Khonensha Seikatsu Jittai Sougo Chosa in Japanese) as a natural experiment to investigate behavioral decision-making of nursing home care and community-based formal/informal home care among the elderly, aged 65 and over. The General Survey is a two-stratified random sample of 3,000 elderly, aged 65 and over, staying at home throughout Japan, and was conducted by the Pension Research Center (the Nenkin Sogo Kenkyu Center in Japanese). The survey was a one-time survey sponsored by the Japan Ministry of Health, Labor and Welfare. The data is the latest one we are able to obtain. The number of respondents who returned their forms was 2,529. As some respondents did not provide the necessary information for this analysis, our sample size became 2,501. The definitions of all variables used in this study and their statistics are reported in Table 2.

Another aspect of the retrospective data analysis for behavioral choice is that the data does not include supply side measures - prices and facility locations. This study does not integrate supply constraints, and this may lead to a biased estimation. However, under the national health insurance system, there are few variations of prices for services to the elderly. Each choice of service costs a different amount, and the cost depends on personal finances. Economic factors (wealth, home ownership and income variables) in this study are used as a proxy for the availability of services. A binary variable of urban-rural differentials is also used to represent taste as well as the accessibility of nursing home and community-based formal home care services. Thus, these economic and demographic variables in our model may mitigate our biased estimation due to the lack of supply side measures. 
The Geneva Papers on Risk and Insurance - Issues and Practice

612

Table 2 Definition of variables and their descriptive statistics

Variable Mean $\begin{gathered}\text { Standard Definition } \\ \text { deviation }\end{gathered}$

Long-term care

Nursing home care

0.2767

Community-based formal

home care

Day\&short center

0.3563

Formal home care

0.7205

Skilled home care

0.7081

Doctor visits

0.5741

Nurse visits

0.3030

Semi-skilled home care

0.4674

Home help visits

0.2307

Bathing

Meals

0.1095

Equipment

0.1583
0.4474

Binary variable: $1=$ behavioral choice to use institutional long-term care (health facility, welfare facility and long-term care for the elderly in Table 1), when an elderly person becomes bedridden

0.4789 Binary variable: $1=$ behavioral choice to use community-based day-service and short-stay facility centers, when an elderly person becomes bedridden Binary variable: $1=$ behavioral choice to use community-based formal home care that excludes Day\&short center, when an elderly person becomes bedridden at home

0.4547 Binary variable: $1=$ behavioral choice to use community-based medical home care service e (doctor visits, nurse visits, etc.), when an elderly person becomes bedridden at home

0.4945 Binary variable: $1=$ behavioral choice to use home health and medical services by doctors, when an elderly person becomes bedridden at home

0.4596 Binary variable: $1=$ behavioral choice to use home health and medical services by nurses, when an elderly person becomes bedridden at home

0.4990 Binary variable: $1=$ behavioral choice to use home care, community-based home care or non-medical home care service (home help visit, bathing, meals, toilet, laundry, etc.), when an elderly person becomes bedridden at home

0.4213 Binary variable: $1=$ behavioral choice to use personal-care assistance and housekeeping, when an elderly person becomes bedridden at home

0.4193 Binary variable: $1=$ behavioral choice to use bathing service at day-service center, when an elderly person becomes bedridden at home

0.3123 Binary variable: $1=$ behavioral choice to use meal delivery services, when an elderly person becomes bedridden at home

Binary variable: $1=$ behavioral choice to use services of special bed supply, wheelchair and other equipment, when an elderly person becomes bedridden at home

Informal home care

0.9345
Informal home care an elderly who spends on meals, dressing, toileting and bathing at home (hours per day) 
Table 2 (continued)

\begin{tabular}{|c|c|c|c|}
\hline Variable & Mean & $\begin{array}{l}\text { Standard } \\
\text { deviation }\end{array}$ & Definition \\
\hline \multicolumn{4}{|l|}{ Availability of family } \\
\hline Married & 0.6261 & 0.4839 & Binary variable: $1=$ married and living with spouse \\
\hline Family & 0.4858 & 0.4998 & $\begin{array}{l}\text { Binary variable: } 1=\text { two and three generation } \\
\text { families or multi-generation family }\end{array}$ \\
\hline No children & 0.3462 & 0.4758 & $\begin{array}{l}\text { Binary variable: } 1=\text { elderly person with children but } \\
\text { does not live together with them }\end{array}$ \\
\hline \multicolumn{4}{|l|}{ Economic factors } \\
\hline Wealth low & 0.2011 & 0.4009 & $\begin{array}{l}\text { Amount of wealth (bonds, stocks, savings and trusts) } \\
\text { less than } 1 \text { million yen }\end{array}$ \\
\hline Wealth high & 0.0559 & 0.2299 & $\begin{array}{l}\text { Amount of wealth (bonds, stocks, savings and trusts) } \\
\text { more than } 30 \text { million yen }\end{array}$ \\
\hline Home owner & 0.8692 & 0.3371 & Binary variable: $1=$ owns house or apartment \\
\hline Income & 193.87 & 131.09 & $\begin{array}{l}\text { Work income, pension, wealth income and welfare } \\
\text { income }(1,000 \text { yen })\end{array}$ \\
\hline \multicolumn{4}{|l|}{ Objective health } \\
\hline $\begin{array}{l}\text { Physical I: five } \\
\text { dependence }\end{array}$ & 0.0136 & 0.1158 & $\begin{array}{l}\text { Five measures of physical dependence in daily } \\
\text { dependence activities: walking without help, } \\
\text { climbing stairs, physical strength represented by bed- } \\
\text { making by himself or herself, hands' and fingers' } \\
\text { ability represented by cutting own nails, and eye } \\
\text { sight ability represented by reading newspapers }\end{array}$ \\
\hline $\begin{array}{l}\text { Physical II: from two to } \\
\text { four dependence }\end{array}$ & 0.2810 & 0.4496 & \\
\hline $\begin{array}{l}\text { Instrumental I: five } \\
\text { dependence }\end{array}$ & 0.0544 & 0.2268 & $\begin{array}{l}\text { Five measures of instrumental dependence of either } \\
\text { using (electric or non-electric) household tools and } \\
\text { machines or performing complicated daily tasks: } \\
\text { preparation of meals, being able to use a washing } \\
\text { machine, being able to use an automatic machine to } \\
\text { deposit/withdraw money at a bank, shopping for } \\
\text { necessities, and being able to fill in forms }\end{array}$ \\
\hline $\begin{array}{l}\text { Instrumental II: from two } \\
\text { to four dependence }\end{array}$ & 0.3042 & 0.4601 & \\
\hline $\begin{array}{l}\text { Memory I: six } \\
\text { dependence }\end{array}$ & 0.0166 & 0.1071 & $\begin{array}{l}\text { Six abilities of daily living: remembering the location } \\
\text { of own clothes, cooking a variety of dishes without } \\
\text { recipes, following community rules and regulations, } \\
\text { remembering the location of important documents, a } \\
\text { choice of clothes by one's own taste and continuation } \\
\text { of having hobbies }\end{array}$ \\
\hline $\begin{array}{l}\text { Memory II: from three to } \\
\text { five dependence }\end{array}$ & 0.2299 & 0.4208 & \\
\hline $\begin{array}{l}\text { Depressed affect I: four } \\
\text { and more depressed affect }\end{array}$ & 0.1611 & 0.3677 & $\begin{array}{l}\text { Seven measures of depressed affect: loneliness, } \\
\text { uselessness, anxiety, sadness, preference for death, } \\
\text { uneasiness and dissatisfaction }\end{array}$ \\
\hline $\begin{array}{l}\text { Depressed affect II: from } \\
\text { one to three depressed } \\
\text { affects }\end{array}$ & 0.5977 & 0.4904 & \\
\hline
\end{tabular}


Table 2 (continued)

\begin{tabular}{|c|c|c|c|}
\hline Variable & Mean & $\begin{array}{l}\text { Standard } \\
\text { deviation }\end{array}$ & Definition \\
\hline \multicolumn{4}{|l|}{ Other factors } \\
\hline Urban & 0.6869 & 0.4638 & Binary variable: $1=$ urban city dweller \\
\hline Gender & 0.4606 & 0.4985 & Binary variable: $1=$ male \\
\hline Age & 71.8 & 5.6 & Age of elderly person \\
\hline Not outgoing & 0.2019 & 0.4015 & $\begin{array}{l}\text { Binary variable: } 1=\text { elderly person who has a } \\
\text { negative attitude toward going out }\end{array}$ \\
\hline No friends & 0.1979 & 0.3985 & $\begin{array}{l}\text { Binary variable: } 1=\text { elderly person who has no close } \\
\text { friends }\end{array}$ \\
\hline Association & 0.3482 & 0.4765 & $\begin{array}{l}\text { Binary variable: } 1=\text { elderly person who frequently } \\
\text { associates with friends }\end{array}$ \\
\hline Communication & 0.3998 & 0.4899 & $\begin{array}{l}\text { Binary variable: } 1=\text { elderly person who frequently } \\
\text { communicates with relatives }\end{array}$ \\
\hline
\end{tabular}

An assessment of the health characteristics of the elderly is often an important issue in the literature. Previous research recommends objective indicators of health status (i.e., ADL (or activities of daily living) and IADL (or instrumental activities of daily living)) because of difficulties in comparing measures of self-evaluated health status among respondents, that is, subjective measures. ${ }^{37}$ Greene et al. ${ }^{38}$ employed three different measurements of health status in their analysis of transition from community to nursing homes: instrumental activities of daily living, cognitive impairment, and self-evaluated health. Nishiwaki et al. ${ }^{39}$ used dependence for activities of daily living. Their results also recommend the use of objective indicators on the health status of the elderly. Using the questionnaire in our data (see Table 2), the study generates the following objective measures of the health status: physical dependence, instrumental dependence, memory, and psychological status (i.e., depressed affect).

Of the other socio-economic and demographic factors studied in this analysis, the study includes economic factors, such as the elderly person's monthly income, wealth, and home ownership. These economic variables reflect not only the monetary value of an elderly person's healthy time but also the capability to pay the monthly charges of the different long-term health care facilities. For the expected effects of the economic variables, since staff intensity and higher skilled staff at nursing homes may represent better quality of services, the elderly with more wealth may prefer a nursing home with better quality, holding the elderly health status and other socio-demographic characteristics constant. ${ }^{40}$ On the other hand, home ownership may reflect a strong psychological and social attachment to the community. ${ }^{41}$ Thus, the expected effect of

\footnotetext{
${ }^{37}$ Kemper (1992); Bound (1991); Liu et al. (1995); Nishiwaki et al. (2005).

${ }^{38}$ Greene et al. (1993).

${ }^{39}$ Nishiwaki et al. (2005).

${ }^{40}$ Cohen and Spector (1996); Arai et al. (2004); Sato et al. (2006).

${ }^{41}$ Kimura (1996).
} 
this variable is negative on the probability of choosing nursing home care. The age and gender variables are expected to reflect health and preference differentials. Variables representing social attitudes among the elderly are also included (i.e., not outgoing, no friends, association, and communication variables).

\section{Empirical results}

Table 3 a presents the estimates of our logit model of nursing home care, communitybased day-service and short-stay facility centers (day\&short center), and skilled home care. These variables are defined in Table 2. Table $3 \mathrm{~b}$ reports the logit estimates of semi-skilled home care and of formal home care, and the ordinary least squares estimates of informal home care. This paper first reviews the major empirical results of each model, and then concentrates its discussion on the interactions among nursing home care, community-based formal home care, and informal home care.

\section{Behavioral determinants: nursing home care, day\&short center and skilled home care}

The first column of Table 3a presents the results of influential factors that affect an elderly person's behavioral choice of nursing home care use when she/he is bedridden. The coefficient of the day\&short center in this specification is statistically significant. An elderly person who wants to use a day\&short center is less likely to use nursing home care services. The variables of skilled home care services such as doctor and nurse visits are positively associated with nursing home care at different levels of significance. The positive influence of skilled home care services by doctors and nurses implies that an elderly person who wants to use nursing home care services when she/ he is bedridden, is influenced by a medical doctor's advice and services at home, and is more likely to be recommended to use nursing home care services. On the other hand, semi-skilled formal home care services, such as home help visits, bathing, and meals services are negatively associated with nursing home care. Interesting results from objective health show that advanced levels of functional limitations of physical and instrumental dependences have significant and positive influences on the use of nursing home care services, while mental and psychological aspects of advanced level of memory dependence and depressed affect have substantial and negative effects on the use of nursing home care services.

The second column of Table 3a shows the coefficients of influential factors on the day\&short center. The evidence shows that an elderly person who wants to use nursing home care services is less likely to use community-based day-services and short-stay facility centers. Skilled home care services by doctor and nurse visits and semi-skilled home care services, including home help visits, bathing, and meals, are statistically significant and have positive influences on day\&short center services. For skilled home care services in column 3 of Table $3 \mathrm{a}$, nursing home care and day\&short center services are negatively associated with skilled home care services, and semi-skilled home care services are positively associated with skilled home care services. Semi-skilled home care services seem to increase the probability of getting skilled home care services. The results of objective health in day\&short centers and skilled home care services do not 
The Geneva Papers on Risk and Insurance - Issues and Practice

616

Table 3a Regression results: nursing home care, day\&short center and skilled home care

\begin{tabular}{|c|c|c|c|c|c|c|}
\hline \multirow{2}{*}{$\begin{array}{l}\text { Variable } \\
\text { Long-term care }\end{array}$} & \multicolumn{2}{|c|}{$\begin{array}{l}\text { Nursing home } \\
\text { care logit }\end{array}$} & \multicolumn{2}{|c|}{$\begin{array}{l}\text { Day\&short } \\
\text { center logit }\end{array}$} & \multicolumn{2}{|c|}{$\begin{array}{l}\text { Skilled home } \\
\text { care logit }\end{array}$} \\
\hline & & & & & & \\
\hline Nursing home care & - & & $-0.177 \mathrm{c}$ & $(0.099)$ & $-0.527 \mathrm{a}$ & $(0.101)$ \\
\hline \multicolumn{7}{|c|}{ Community-based formal home care } \\
\hline Day\&short center & $-0.195 b$ & $(0.099)$ & - & & $-0.278 \mathrm{a}$ & $(0.094)$ \\
\hline \multicolumn{7}{|l|}{ Formal home care } \\
\hline Skilled home care & - & & - & & - & \\
\hline Doctor visits & $0.474 \mathrm{a}$ & $(0.95)$ & $0.497 \mathrm{a}$ & $(0.088)$ & - & \\
\hline Nurse visits & 0.056 & $(0.103)$ & $0.203 b$ & $(0.094)$ & - & \\
\hline Semi-skilled home care & - & & - & & $0.583 \mathrm{a}$ & $(0.093)$ \\
\hline Home help visits & $-0.508 \mathrm{a}$ & $(0.106)$ & $0.246 \mathrm{~b}$ & $(0.105)$ & - & \\
\hline Bathing & -0.199 & $(0.112)$ & $0.263 \mathrm{~b}$ & $(0.105)$ & - & \\
\hline Meals & $-0.310 \mathrm{~b}$ & $(0.144)$ & $0.753 \mathrm{a}$ & $(0.158)$ & - & \\
\hline Equipment & 0.067 & $(0.134)$ & 0.014 & $(0.117)$ & - & \\
\hline Informal home care & $-0.064 b$ & $(0.026)$ & 0.019 & $(0.026)$ & -0.012 & $(0.026)$ \\
\hline \multicolumn{7}{|l|}{ Availability of family } \\
\hline Married & 0.191 & $(0.121)$ & -0.108 & $(0.112)$ & 0.172 & $(0.117)$ \\
\hline Family & $0.249 \mathrm{~b}$ & $(0.101)$ & $-0.289 \mathrm{a}$ & $(0.092)$ & 0.071 & $(0.097)$ \\
\hline No children & $0.208 \mathrm{a}$ & $(0.100)$ & -0.035 & $(0.091)$ & $-0.189 b$ & $(0.096)$ \\
\hline \multicolumn{7}{|l|}{ Economic factors } \\
\hline Wealth low & -0.133 & $(0.120)$ & -0.101 & $(0.112)$ & $-0.255 b$ & $(0.114)$ \\
\hline Wealth high & 0.097 & $(0.231)$ & 0.119 & $(0.206)$ & 0.016 & $(0.226)$ \\
\hline Home owner & $0.418 \mathrm{a}$ & $(0.137)$ & -0.072 & $(0.141)$ & 0.191 & $(0.140)$ \\
\hline Income & 0.001 & $(0.001)$ & $-0.001 b$ & $(0.001)$ & -0.001 & $(0.001)$ \\
\hline \multicolumn{7}{|l|}{ Objective health } \\
\hline Physical dependence I & $1.738 \mathrm{a}$ & $(0.671)$ & -0.351 & $(0.400)$ & $-0.869 b$ & $(0.412)$ \\
\hline Physical dependence II & 0.188 & $(0.135)$ & 0.077 & $(0.120)$ & -0.191 & $(0.127)$ \\
\hline Instrumental dependence I & $0.527 \mathrm{c}$ & $(0.302)$ & -0.246 & $(0.245)$ & $0.515 \mathrm{c}$ & $(0.268)$ \\
\hline Instrumental dependence II & 0.041 & $(0.131)$ & 0.034 & $(0.118)$ & $0.227 \mathrm{c}$ & $(0.128)$ \\
\hline Memory I & $-1.326 \mathrm{a}$ & $(0.468)$ & 0.297 & $(0.443)$ & 0.239 & $(0.497)$ \\
\hline Memory II & -0.074 & $(0.143)$ & $0.270 \mathrm{~b}$ & $(0.129)$ & $-0.226 \mathrm{c}$ & $(0.136)$ \\
\hline Depressed affect I & $-0.396 b$ & $(0.156)$ & $-0.286 c$ & $(0.146)$ & $0.309 \mathrm{~b}$ & $(0.154)$ \\
\hline Depressed affect II & -0.147 & $(0.118)$ & $-0.213 b$ & $(0.106)$ & 0.162 & $(0.110)$ \\
\hline \multicolumn{7}{|l|}{ Other factors } \\
\hline Urban & $-0.221 b$ & $(0.110)$ & 0.109 & $(0.097)$ & 0.164 & $(0.103)$ \\
\hline Gender (male) & 0.125 & $(0.117)$ & -0.155 & $(0.107)$ & $0.338 \mathrm{a}$ & $(0.114)$ \\
\hline Age & -0.003 & $(0.009)$ & 0.007 & $(0.008)$ & -0.001 & $(0.009)$ \\
\hline Not outgoing & $0.315 b$ & $(0.131)$ & 0.031 & $(0.120)$ & -0.109 & $(0.124)$ \\
\hline No Friends & $-0.397 \mathrm{a}$ & $(0.125)$ & $0.200 \mathrm{c}$ & $(0.121)$ & $-0.350 \mathrm{a}$ & $(0.125)$ \\
\hline Association & 0.162 & $(0.111)$ & $0.167 \mathrm{c}$ & $(0.099)$ & $-0.223 b$ & $(0.105)$ \\
\hline Communication & 0.133 & $(0.100)$ & -0.071 & $(0.090)$ & -0.041 & $(0.096)$ \\
\hline Intercept & 0.584 & $(0.705)$ & 0.096 & $(0.648)$ & 0.669 & $(0.677)$ \\
\hline$\chi^{2}$ & 205.75 & & 118.39 & & 141.37 & \\
\hline-2 Log likelihood & 2744.4 & & 3139.1 & & 2878.9 & \\
\hline Sample size & 2501 & & 2501 & & 2501 & \\
\hline
\end{tabular}

Note: Standard errors are in parentheses. a, b and c represent statistically significant levels of logit coefficients as follows: 99 per cent level(a), 95 per cent level(b) and 90 per cent level(c) for a two-tailed test. 
Tetsuji Yamada et al Community-based formal and informal home care

Table 3b Regression results: semi-skilled home care, formal home care and informal home care

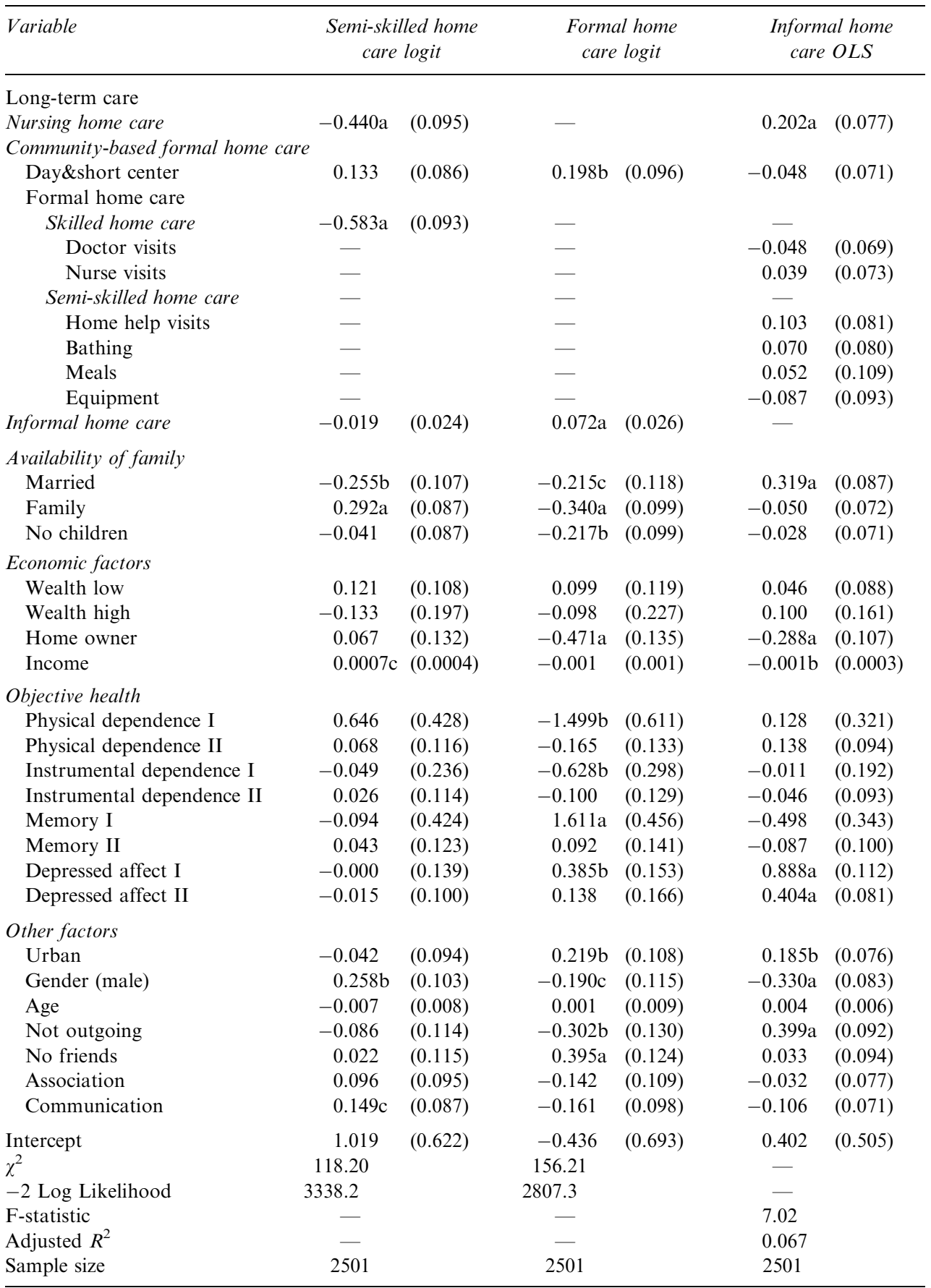

Note: Standard errors are in parentheses. a, b and c represent statistically significant levels of logit and OLS coefficients as follows: 99 per cent level(a), 95 per cent level(b) and 90 per cent level(c) for a two-tailed test. 
show comprehensible systematic influences on an elderly person's behavioral choice, and an elderly person with instrumental dependence I or II is more likely to get skilled home care services.

\section{Behavioral determinants: semi-skilled home care, formal home care and informal home} care

The coefficient of nursing home care in the model of semi-skilled home care services is statistically significant and negative in the first column of Table $3 \mathrm{~b}$. An implication of the result is that the negative coefficients of semi-skilled home care services (home help visits, bathing and meals) in the nursing home equation of Table 3a display the substitutive relationship between semi-skilled home care services and nursing home care services. Skilled home care services are likely to reduce the probability of using semi-skilled home care services. Not surprisingly, day\&short centers have positive influences on formal home care (defined in Table 2), and the result is congruent with the signs of skilled home care (doctor and nurse visits) and semi-skilled home care (home help visits, bathing and meals) services in the day\&short center model in Table 3a. Despite our recommendation in favor of community-based formal home care use instead of nursing home care use for cost-containment purposes, policymakers need to be fully aware that the communitybased formal home care services (day\&short center, doctor and nurse visits, home help visits, bathing, meals and equipment) neither mitigate nor encourage informal home care use by the elderly, since none of the estimated coefficients are statistically significant in the informal home care equation (OLS) in Table 3b. Based on the results, the study implies that the national government's attempt to provide more community-based formal care services to reduce expensive institutional care, such as nursing home care services, is an effective cost-containment policy. However, a simple expansion of this service provision will not lead to an increase in informal home care by family caregivers, and neither raises nor reduces the burden of care on family members.

As for the objective health condition in the second column of Table 2, the elderly with higher physical and instrumental dependence tend to choose less formal home care services in the second column of Table $3 \mathrm{~b}$, as was hypothesized. On the other hand, the elderly with both high memory impairment and the depression affect used more formal home care services, while the elderly with only the depression affect used informal home care. This evidence highlights, to some extent, the reality of a shortage of public long-term institutions that care for the Japanese elderly with memory and mental health impairments.

Substitutive or complementary relationship and interaction: nursing home care, day\&short center and skilled home care

Interesting findings are that nursing home care, day\&short center, and skilled home care services interactively influence each other, and are found to be the major determinants of behavioral choice of long-term care services. We also note that 
physical and instrumental dependences, and memory and depressed affect are important determinants on choices of long-term care services. ${ }^{42}$

First, for the interactions of nursing home care, day\&short center, and skilled home care in Table $3 \mathrm{a}$, the study shows that the estimated coefficients of nursing home care as a regressor are statistically significant and negative in both the day\&short center (the second column) and skilled home care (the third column) equations. That is, an elderly person who wants to use nursing home care services when she/he is bedridden is less likely to use community-based day-services and short-stay facility centers, and skilled home care services. Second, the estimated coefficients of the day\&short center as a regressor in the equations of nursing home care (the first column) and skilled home care (the third column) are also negative and statistically significant. There is a tendency for the elderly to substitute day\&short center services for nursing home care and skilled home care services. Therefore, from a cost perspective, an expansion of less costly community-based formal home care programs such as dayservice and short-stay facility centers would lead to a reduction in the use of costly nursing homes.

The six formal home care services under skilled and semi-skilled home care in the second column of Table $3 \mathrm{a}$ are all positively associated and mostly statistically significant in the day\&short center equation. Thus, the elderly who demand these formal home care services tend to use day\&short centers at the same time. In other words, the relationship between the six formal home care services and the day\&short centers is complementary. This result has an important implication for policy development regarding community-based formal home care services within a locality. The positive effects of both doctor and nurse visits in the day\&short center equation in the second column of Table 3a may seem contradictory, since, as noted earlier, the day\&short center is negatively related with skilled home care in the third column of Table 3a. It is, however, not necessarily so. Medical doctors and nurses who visit the elderly at home are very likely to encourage them to utilize the day\&short centers for rehabilitation. An increase in the use of skilled home care increases both nursing home use and day\&short center use. The nursing home care use may decline as a result of the increase in day\&short center use. The encouragement given by doctors and nurses are highly recommended and cost-effective. That is, the more frequently the day\&short centers are used, the less likely both nursing home and skilled home care will be used. Besides, the less frequent use of skilled home care can further reinforce the reduction of nursing home use (see positive effect of doctor visits on nursing home care). As a consequence, cost-containment effects should take place.

To examine whether informal home care is substitutable for nursing home care and community-based formal home care, this study clarifies the relationships among nursing home care, community-based formal home care, and informal home care. In the first column of Table $3 \mathrm{a}$, the estimated coefficient of informal home care is negative $(-0.064)$ and statistically significant in the nursing home care equation, but not significant in both day\&short center and skilled home care equations. It is evident that informal home care can be a substitute for nursing home care, but not for

${ }^{42}$ Himes et al. (2001); Geerlings et al. (2005); Puts et al. (2005). 
620

community-based formal home care. That is, the elderly, who are receiving more informal home care, are less willing to use nursing home care when they become bedridden. The marginal effect and estimated elasticity of nursing home care with respect to informal home care (a continuous variable) are -0.013 and -0.043 , respectively. ${ }^{43} \mathrm{~A}$ one-hour increase in the use of informal home care per day lowers the use of nursing home care by 1.3 percentage points. This effect of informal home care will be large on a weekly or monthly basis. In elasticity terms, a 10 per cent increase in informal home care use leads to a 0.43 per cent decrease in nursing home care use. If the average time spent on informal home care use is doubled, the effect of informal home care given by a family member on nursing home care use will be about 4 per cent.

Substitutive or complementary relationship and interaction: semi-skilled home care, formal home care and informal home care

As shown in the second column of Table 3b, since the effect of nursing home care on informal home care is positive (0.202), the substitution between informal home care and nursing home care is not dual, but a one-way direction from the former to the latter. Informal home care is not a significant determinant for community-based dayservice and short-stay facility centers (day\&short center) in Table 3a, skilled home care in Table 3a, and semi-skilled home care in Table 3b, and vice versa, separately. This seems to be indicative of the strong preference of the Japanese elderly for informal home care provided by family caregivers, regardless of a provision of communitybased formal home care services. However, when we group the above formal home care services together with the formal home care equation in the second column of Table $3 \mathrm{~b}$, the result is somewhat different: the estimated coefficient of informal home care is 0.072 , which is statistically significant. Its marginal effect implies that a $10-\mathrm{h}$ increase in informal care tends to raise the probability of formal home care use by 3 percentage points in the second column of Table $3 \mathrm{~b}$. Its elasticity implies that a 10 per cent increase in informal home care hours per day will lead to a 0.18 per cent increase in formal home care use in general.

The Japan Ministry of Health, Labor and Welfare reports that one third of family caregivers feel that they lack the appropriate knowledge requisite for elderly care and that they need guidance and training in day\&short centers. The present results, however, indicate that this need probably does not mean that they want to substitute community-based formal home care with informal home care, but might only mean that they want the appropriate guidance and training for their specialization in informal home care. Hence, the national and local governments need to carefully assess what kind of assistance is most necessary, appropriate and desirable for the bedridden elderly who want to remain at home with family caregivers.

\footnotetext{
${ }^{43}$ The value of marginal effect, -0.013 , is obtained from $-0.064 \times$ sample average of probability of nursing home care $\times(1$-sample average of prob. of n.h.c $)=-0.064 \times 0.2767 \times 0.7233=-0.0128$. The estimated elasticity is $-0.064 \times(1$-sample average of prob. of n.h.c. $) \times$ sample average of informal home care: $-0.064 \times(1-0.2767) \times 0.9345=-0.0432$.
} 


\section{Socio-demographic and economic factors}

Turning to the availability of family caregivers, considering factors such as the presence of a spouse, family structure, and living arrangement with children, there are some noteworthy results. First, when looking closely at the estimated coefficients of the variable "married" (i.e., married and living with spouse), the effects are statistically significant, and are negative in the semi-skilled home care (the first column) and formal home care (the second column) estimations, but significantly positive in the informal home care (the third column) in Table $3 b$, while not significant at all in the nursing home care, day\&short center and skilled home care models in Table $3 \mathrm{a}$. As the study by Iwamoto ${ }^{44}$ showed, it is very clear from these results that a living spouse is commonly the primary caregiver for a frail elderly person. The spouse tends to substitute his/her informal home care mainly for non-medical community-based formal home care services.

By assessing the regression results of the formal home care in the second column of Table $3 \mathrm{~b}$, the availability of family members as caregivers is negatively associated with formal home care. The cross-comparison of the estimated coefficients of "married" among the semi-skilled home care, formal home care and informal home care models in Table $3 \mathrm{~b}$ shows the consistency of the effects: the married status is negatively associated with semi-skilled and formal home care and is positively related with informal home care. The results show that an availability of family resources, namely married status, seems to be a good substitute for lower level non-medical or semiskilled community-based formal home care services.

The elderly person in a two-or-more-generation family is more willing to use nursing home care (see the positive effect of "family" in the first column of Table 3a) than one in a one-generation family. We would normally expect more available hands in a larger family size. This may not necessarily be the case if the youngest generation consists of dependent children. On the other hand, as we expected, the elderly who do not live together with their children are at a high risk of long term institutional care; this is also implied by the significantly positive coefficient of "No children" in the nursing home equation in Table $3 \mathrm{a}$.

The empirical results of economic and demographic factors are assessed. First, "home owner", as one of the economic variables, has a strong positive effect on nursing home care (the first column) in Table 3a, but has strong negative effects on formal home care (the second column) and informal home care (the third column) in Table 3b. Our results reject a hypothesis of a strong psychological and social attachment to the community. Second, of the socio-demographic variables, by looking at the estimated coefficients in the informal home care model in Table 3b, we note that the coefficient of gender with a negative sign indicates that the female elderly, who are urban dwellers but are not-outgoing types, strongly prefer informal home care to semi-skilled home care to their male elderly counterparts. In contrast, the male elderly are more likely to use skilled and semi-skilled formal home care than the female elderly.

\footnotetext{
${ }^{44}$ Iwamoto (2000).
} 


\section{Discussion and conclusion}

Before describing the policy implications of the study, a few clarifications should be made. Although some empirical and theoretical studies have shown a relationship between nursing home care and home care in the framework of long-term care for the elderly, there is little empirical work documenting elderly behavioral choices regarding the interaction among nursing home care, community-based formal home care, and informal care. First, this study uses the General Survey on Actual Living Conditions of the Elderly of 1990 as a natural experiment to analyze the elderly behavioral decision-making of nursing home care and community-based formal/informal home care. Second, the study does not incorporate supply facilities and their prices of various services for elderly care due to data availability. Thus, there is not perfect control for the supply side factors. Third, our assumption of this study is based on perfect information, not including search costs, and on constant average health care costs for the elderly for the transfer from an institutionalized care to formal/informal home care.

Empirical findings of this study have many important policy implications for containing the rapidly growing national health care expenditures of the elderly and long-term health care services under the public long-term insurance plan. What are the determinants of long-term health care services? Is it possible to substitute less costly community-based formal home care for institutional nursing home care? The answer is an affirmative one. The findings show the existence of a two-way substitution between nursing home care and day\&short centers (community-based day-service and shortstay facility centers) or semi-skilled home care (community-based non-medical home care service, e.g., home help visit, bathing, meal service, etc), as well as a one-way substitution of informal home care for nursing home care. The results suggest that the Japanese public long-term care insurance for the elderly (LTCI) program should be emphasized to develop the close network of day\&short centers, semi-skilled home care services, and informal home care services for efficient resource utilization and cost-effective service delivery. Moreover, the results show that the elderly who have advanced levels of physical impairment rely on the use of nursing home care services, while the elderly with memory dependence and depressed affect use more communitybased formal and informal care services. For that reason, the development of the community-based formal home care services for the elderly with physical and functional impairment is fundamental.

One important issue needs to be emphasized in the establishment of a communitybased formal home care network under the LTCI program. The elderly have strong preferences toward informal home care in the community. However, they often end up with long-term hospital or institutional care (long-term care welfare facilities or longterm care health facilities) due to the lack of a community-based formal home care network (semi-skilled, skilled home care services, community-based day-service and short-stay facility centers, etc.). Lengthy hospital stays as well as use of the most expensive long-term care programs by the elderly (and with relatively low out-ofpocket expenses under the current national health insurance system) are common occurrences and have been causes of increases in health care expenditures. The purposes of the LTCI are to lessen lengthy hospital stays, to call for efficient health 
care resource utilization and to mitigate the physical, mental and financial burden of family caregivers. As a consequence, the LTCI program would reduce a rapid increase in national health care spending. Thus, it is especially important to establish an extensive network for long-term care services, namely semi-skilled home care services, community-based day services, short-stay centers, and nursing home care facilities. The LTCI network must also have information about the services and the facility capability for consumers (households and the elderly), which would be provided by the current jurisdictions of the local municipal and prefectural governments. In addition, appropriate guidance and training for the caregivers would be useful to maintain a resource of the efficient use of community-based formal home care services in the local jurisdiction.

The results indicate that there is a complementary relationship between skilled and semi-skilled home care services (doctor visits, nurse visits, home help visits, etc.) and day\&short centers in the community-based formal home care network. These findings strongly support and help to facilitate the LTCI program under the local government jurisdiction that has been intended to develop community-based formal/informal home care through appropriate networks in the institutional care facilities. Two remarks have to be made pertaining to the LTCI program for the elderly. This study shows, first, that a provision of community-based formal home care services does not give family caregivers incentives to change the amount of their informal home care at home. Second, elderly who receive more informal home care are less likely to use nursing home care when they become bedridden. As expected, the Japanese elderly strongly prefer informal home care provided by family caregivers at home to institutional long-term care. As the elderly desire informal home care much more, more attention needs to be paid to the provision of appropriate incentives to family informal caregivers. Information of each type of community-based formal home care services (e.g. provision, requirement, service capability, etc.) is needed to facilitate the LTCI program, ${ }^{45}$ and compensation to family caregivers for their opportunity costs and in order to reduce their increased burden could both be viable options to effectively integrate informal home care with community-based formal home care programs under the LTCI program.

Another noteworthy finding is that the informal home care positively influences the probability of using skilled and semi-skilled formal home care services at home instead of in an institutional setting. According to our empirical results, an increase in informal care negatively affects nursing home care use through the community-based formal home care services in two ways. One is a negative direct effect on nursing home care services, caused by increasing semi-skilled home care services (home help visits, bathing, meal service, etc.). The second is a negative indirect effect on nursing home care services. Elderly people who are under informal home care tend to use semiskilled home care services, which create additional incentives for the elderly with informal home care to use the day\&short center. Use of the day\&short center is also significantly associated with a lower probability of being in an institutional setting for the elderly. As a result, the development of the community-based formal home care

\footnotetext{
${ }^{45}$ Horiguchi et al. (2004).
} 
with transferring the elderly from institutional long-term care to less costly community-based formal home care would lead to economic gains.

The aforementioned estimation is made to meet the desire of most of the elderly to live within the community. Does the LTCI program guarantee that choice for the elderly? The answer is partially affirmative. A local government official, as a planner, decides and recommends a package of services within the budgetary constraints, and in accordance with the regulations that meet the needs of the elderly. Differences in the individual characteristics of the elderly (i.e., health conditions, availability of family caregivers, and other socio-economic and demographic factors) certainly require different community-based formal and informal home care services. Thus, the national as well as local governments must carefully screen the elderly to identify differences in their priorities, and to consequently provide the most desirable long-term care services within the community. The means which make the LTCI program successful depend on efficiency, effectiveness and fairness. However, it is still difficult to anticipate enough services for the elderly in the communities. The LTCI program allows forprofit organizations to participate in the home-based service market as service providers. The for-profit organizations may not participate or may not provide services to meet market needs/demand, if the local government reimbursement is too low to cover the costs of the operation. Hence, it is possible and essential that the national and local governments entitle private sector insurers to establish a private insurance market for the long-term care services, especially community-based formal home care services, to fill the gap between supply and demand by emphasizing the benefit approach.

Having the appropriate networks with information about services and also having requirements for community-based formal and informal home care are important in promoting the current long-term insurance program. The success of such health care initiatives largely depends on how carefully the programs of community-based formal and informal home care are designed. This study provides strong evidence of the negative relationships between nursing home care and community-based formal home care. It also shows that informal home care negatively affects nursing home care. Therefore, well-organized and well-developed community-based formal and informal home care programs are viable substitution options for costly institutionalized longterm care in hospitals and in nursing homes. Such a long-term care policy may significantly contain the rapidly growing government health care expenditures.

\section{Acknowledgements}

We are indebted to Michael Grossman, Bernard Okun, Charlotte Muller, Haruko Noguchi, Chang-Gun Kim, and the seminar participants of the NBER Summer Seminar. The authors would like to thank Hideo Ibe of the Nenkin Sogo Kenkyu Center (Japan) and Yuriko Sato of the International Leadership Center on Longevity and Society (Japan). We also gratefully acknowledge the research support from the Research Council of Rutgers University, the Center for the Global Partnership of Japan Foundation, the International Longevity Center (Japan/U.S.), the Nomura Foundation for Social Science, and grant number 14530042, Grant-in-Aid Scientific Research (C), from Japan Society for the Promotion of Science (JSPS). The views presented here are those of the authors and do not necessarily represent those of the funding agencies nor those of the affiliated institutions. Finally, we wish to thank Clayton T. Cook for his research assistance at Rutgers University, the State University of New Jersey, U.S.A. 


\section{References}

Aneshensel, C.S., Pearlin, L.I., Mullan, J.T., Zarit, S.H. and Whitlatch, C.J. (1995) Profiles in Care Giving: The Unexpected Career, San Diego: Academic Press.

Arai, Y. (2004) 'Family caregiver burden in the context of the long-term care insurance system', Journal of Epidemiology 14(5): 139-142.

Arai, Y., Kumamoto, K., Washio, M., Ueda, T., Miura, H. and Kudo, K. (2004) 'Factors related to feelings of burden among caregivers looking after impaired elderly in Japan under the Long-Term Care insurance system', Psychiatry and Clinical Neurosciences 58(4): 396-402.

Bauer, E.J. (1996) 'Transitions from home to nursing home in a capitated long-term care program: the role of individual support systems', Health Services Research 31(3): 309-326.

Bound, J. (1991) 'Self-reported versus objective measures of health in retirement models', Journal of Human Resources 26(1): 106-138.

Charles, K.K. and Sevak, P. (2005) 'Can family caregiving substitute for nursing home care?', Journal of Health Economics 24(6): 1174-1190.

Chuma, H., Yamada, T. and Yasukawa, F. (1994) The demand for long- term care of the aged in Japan, Paper presented at NBER-JCER Conference on the Economics of Health Care, Hawaii, U.S.A.

Cohen, J.W. and Spector, W.D. (1996) 'The effect of Medicaid reimbursement on quality of care in nursing homes', Journal of Health Economics 15(1): 23-48.

Coughlin, T.A., McBride, T.D., Perozek, M. and Liu, K. (1992) 'Home care for the disabled elderly: predictors and expected costs', Health Services Research 27(4): 453-479.

Deaton, A. and Muellbauer, J. (1984) Economics and Consumer Behavior, Cambridge, UK: Cambridge University Press.

Ettner, S.L. (1994) 'The effect of the Medicaid home care benefit on long-term care choices of the elderly', Economic Inquiry 32(1): 103-127.

Gaugler, J.E., Anderson, K.A., Zarit, S.H. and Pearlin, L.I. (2004) 'Family involvement in nursing homes: effects on stress and well-being', Aging \& Mental Health 8(1): 65-75.

Geerlings, S.W., Pot, A.M., Twisk, J.W.R. and Deeg, D.J.H. (2005) 'Predicting transitions in the use of informal and professional care by older adults', Ageing \& Society 25: 111-130.

Grabowski, D.C. (2001) 'Medicaid reimbursement and the quality of nursing home care', Journal of Health Economics 20: 549-569.

Grabowski, D.C. and Gruber, J. (2005) Moral hazard in nursing home use, NBER Working Paper No. 11723.

Grabowski, D.C., Angelelli, J.J. and Mor, V. (2004) 'Medicaid payment and risk-adjusted nursing home quality measures', Health Affairs (Millwood) 23(5): 243-252.

Greene, V.L. (1983) 'Substitution between formally and informally provided care for the impaired elderly in the community', Medical Care 21(6): 609-619.

Greene, V.L., Lovely, M.E. and Ondrich, J.I. (1993) 'Do community-based, long-term-care services reduce nursing home use? A transition probability analysis', Journal of Human Resources 28(2): 297-317.

Gujarati, D. (1999) Essential of Econometrics (2nd ed), New York: Irwin/McGraw-Hill.

Hausman, J.A. (1978) 'Specification tests in econometrics', Econometrica 46: 1251-1271.

Himes, C.L., Schneider, U. and Wolf, D.A. (2001) 'The dynamics of long-term care service use in Germany', Vierteljahrshefte zur Wirtschaftsforschung 70: 153-158.

Horiguchi, H., Hara, Y., Ikeda, H. and Nobutomo, K. (2004) 'Differences in facilities' acceptance of patients under long-term care insurance in Japan', Journal of Aging \& Social Policy 16(3): 57-70.

Ikegami, N., Fries, B.E., Takagi, Y., Ikeda, S. and Ibe, T. (1994) 'Applying RUG-III in Japanese long-term care facilities', Gerontologist 34(5): 628-639.

Iwamoto, Y. (2000) 'How does the provision of home care affect the labor force participation of family members?', The Quarterly of Social Security Research 36(3): 321-337.

Kemper, P. (1992) 'The use of formal and informal home care by the disabled elderly', Health Services Research 27(4): 421-451.

Kimura, Y. (1996) 'The estimates of the public insurance for the elderly care and it's economic effects', JCER Economic Journal 33: 145-174.

Kobayashi, Y. and Reich, M.R. (1993) 'Health care financing for the elderly in Japan', Social Science \& Medicine 37(3): 343-353. 
626

Kokumin Eisei no Doukou (1997) 'Health and Welfare Statistical Association', Vol. 44, Tokyo.

Kokumin Eisei no Doukou (2004) 'Health and Welfare Statistical Association', Vol. 51, Tokyo.

Kokumin Fukushi no Doukou (2000) 'Health and Welfare Statistical Association', Vol. 47, Tokyo.

Kokumin Fukushi no Doukou (2004) 'Health and Welfare Statistical Association', Vol. 51, Tokyo.

Kokumin Fukushi no Doukou (2005) 'Health and Welfare Statistical Association', Vol. 52, Tokyo.

Kurimori, S., Fukuda, Y., Nakamura, K., Watanabe, M. and Takano, T. (2006) 'Calculation of prefectural disability-adjusted life expectancy (DALE) using long-term care prevalence and its socioeconomic correlates in Japan', Health Policy 76(3): 346-358.

Lakdawalla, D. and Philipson, T. (1999) Aging and the growth of long-term care, NBER Working Paper No.6980.

Lakdawalla, D. and Schoeni, R. (2003) 'Is nursing home demand affected by the decline in age differences between spouses', Demographic Research 8(10): 279-304.

Liu, X., Liang, J., Muramatsu, N. and Sugiyama, H. (1995) 'Transitions in functional status and active life expectancy among older people in Japan', Journal of Gerontology 50B(6): 383-394.

Mellor, J.M. (2001) 'Long-term care and nursing home coverage: are adult children substitutes for insurance policies?', Journal of Health Economics 20(4): 527-547.

Mor, V., Zinn, J., Angelelli, J., Teno, J.M. and Miller, S.C. (2004) 'Driven to tiers: socioeconomic and racial disparities in the quality of nursing home care', The Milbank Quarterly 82(2): 227-256.

Moscovice, I., Davidson, G. and McCaffrey, D. (1988) 'Substitution of formal and informal care for the community-based elderly', Medical Care 26(2): 971-981.

Nakamura, A. and Nakamura, M. (1981) 'On the relationships among several specification error tests presented by Durbin, Wu, and Hausman', Econometrica 49: 1583-1588.

Nishiwaki, T., Nakamura, K., Ueno, K., Fujino, K. and Yamamoto, M. (2005) 'Health characteristics of elderly Japanese requiring care at home', The Tohoku Journal of Experimental Medicine 205(3): 231-239.

Ogura, S. and Oishi, A. (1994) Hospital regulations and the long-term care of the aged in Japan, Paper presented at NBER-JCER Conference on the Economics of Health Care, Hawaii, U.S.A.

Ohkusa, Y. (2000) 'Empirical analysis to the market of the social insurance for elderly care', The Quarterly of Social Security Research 36(3): 338-352.

Oura, A., Washio, M., Wada, J., Arai, Y. and Mori, M. (2006) 'Factors related to institutionalization among the frail elderly with home-visiting nursing service in Japan', Gerontology 52(1): 66-68.

Paulus, A.T., Raak, A. and Keijzer, F. (2005) 'Informal and formal caregivers' involvement in nursing home care activities: impact of integrated care', Journal of Advanced Nursing 49(4): 354-366.

Portrait, F., Lindeboom, M. and Deeg, D. (2000) 'The use of long-term care services by the Dutch elderly', Health Economics 9(6): 513-531.

Puts, M.T.E., Lips, P., Ribbe, M.W. and Deeg, D.J.H. (2005) 'The effect of frailty on residential/nursing home admission in the Netherlands independent of chronic disease and functional limitations', European Journal of Ageing 2: 264-274.

Report of Social Security Committee (2004) Reevaluation of the Japanese Public Long-term Care Insurance Program (Kaigohoken Seido no Minaoshi ni Tsuite in Japanese) (June), Chuou Houki, Tokyo.

Sato, M., Hashimoto, H., Tamiya, N. and Yano, E. (2006) 'The effect of a subsidy policy on the utilization of community care services under a public long-term care insurance program in rural Japan', Health Policy 77(1): 43-50.

Stern, S. (1995) 'Estimating family long-term care decisions in the presence of endogenous child characteristics', Journal of human Resources 30(3): 551-580.

Swan, J.H. and Benjamin, A.E. (1990) 'Medicare home health utilization as a function on nursing home market factors', Health Services Research 25(3): 479-500.

Wooldridge, J.M. (2003) Introductory Econometrics: A Modern Approach (2nd ed), Mason, Ohio: SouthWestern College Publishing. 


\begin{tabular}{|c|c|c|c|c|c|c|}
\hline Authors & Setting & Design and Method & Data Sources & Time Horizon & Sample Size & Major Findings \\
\hline \multicolumn{7}{|c|}{ Formal and informal home care } \\
\hline $\begin{array}{l}\text { Charles and } \\
\text { Sevak (2005) }\end{array}$ & $\begin{array}{l}\text { Children's gender, } \\
\text { marital status, and } \\
\text { geographic location }\end{array}$ & $\begin{array}{l}\text { OLS vs. TSLS } \\
\text { estimation }\end{array}$ & $\begin{array}{l}\text { Asset \& Health } \\
\text { Dynamics of the } \\
\text { Oldest Old Study }\end{array}$ & $1993-2000$ & 6,855 & $\begin{array}{l}\text { Reduction of future } \\
\text { nursing home use by } \\
\text { informal home care }\end{array}$ \\
\hline $\begin{array}{l}\text { Geerlings et al. } \\
(2005)\end{array}$ & Aged 55-85 Netherlands & $\begin{array}{l}\text { Transition from no } \\
\text { care to informal and } \\
\text { formal cares; } \\
\text { predisposing, enabling } \\
\text { and need factors }\end{array}$ & $\begin{array}{l}\text { Longitudinal Aging } \\
\text { Study Amsterdam } \\
\text { (LASA) }\end{array}$ & $\begin{array}{l}1992-1993, \\
1995-1996 \text { and } \\
1998-1999\end{array}$ & $\begin{array}{l}\text { Baseline } 3,107 \text {; and } \\
\text { follow-up interview } \\
2,469\end{array}$ & $\begin{array}{l}\text { Age, education, income, } \\
\text { physical limitation, } \\
\text { depression, and } \\
\text { cognitive impairment }\end{array}$ \\
\hline $\begin{array}{l}\text { Paulus et al. } \\
(2005)\end{array}$ & $\begin{array}{l}\text { Two nursing homes in } \\
\text { Netherlands }\end{array}$ & $\begin{array}{l}\text { Quasi-experimental } \\
\text { design with an } \\
\text { integrated care } \\
\text { intervention }\end{array}$ & $\begin{array}{l}\text { Before intervention } \\
\text { May/June } 2000 \text { and } \\
\text { twice after }\end{array}$ & $\begin{array}{l}\text { September } \\
1999 \text { - February } \\
2003\end{array}$ & $\begin{array}{l}\text { Residents (84-101); } \\
\text { caregivers (234-239) }\end{array}$ & $\begin{array}{l}\text { Limited amount of } \\
\text { substitution of informal } \\
\text { care for formal care }\end{array}$ \\
\hline $\begin{array}{l}\text { Himes et al. } \\
(2001)\end{array}$ & $\begin{array}{l}\text { Need for informal and } \\
\text { formal cares in } \\
\text { Germany }\end{array}$ & $\begin{array}{l}\text { Help with tasks in the } \\
\text { home and out of the } \\
\text { home }\end{array}$ & $\begin{array}{l}\text { German Socio- } \\
\text { Economic Panel } \\
(\text { GSOEP) }\end{array}$ & 1985-1990 & 3,842 & $\begin{array}{l}\text { Single, childless and } \\
\text { poor health elderly }\end{array}$ \\
\hline Mellor (2001) & $\begin{array}{l}\text { Long-term care } \\
\text { insurance }(\mathrm{LTCI}) \text { and } \\
\text { caregivers }\end{array}$ & $\begin{array}{l}\text { Current and future } \\
\text { informal help and } \\
\text { long-term care } \\
\text { insurance }\end{array}$ & $\begin{array}{l}\text { Study of Asset and } \\
\text { Health Dynamics }\end{array}$ & 1993 & 7,775 & $\begin{array}{l}\text { No effect of availability } \\
\text { of informal care on } \\
\text { LTCI }\end{array}$ \\
\hline $\begin{array}{l}\text { Portrait et al. } \\
(2000)\end{array}$ & $\begin{array}{l}\text { Elderly } 65+\text { in } \\
\text { Netherlands; health, } \\
\text { socio-demographic and } \\
\text { economic factors }\end{array}$ & $\begin{array}{l}\text { Utilization of formal } \\
\text { care (including } \\
\text { institutional care) } \\
\text { services }\end{array}$ & $\begin{array}{l}\text { Longitudinal Aging } \\
\text { Study Amsterdam } \\
\text { (LASA) }\end{array}$ & $\begin{array}{l}\text { T1: 1992-1993 } \\
\text { T2:1995-1996 }\end{array}$ & $\begin{array}{l}\mathrm{T} 1=3,107 ; \text { and } \\
\mathrm{T} 2=1,659\end{array}$ & $\begin{array}{l}\text { Physical disability, } \\
\text { cognitive limit, health } \\
\text { status, and education }\end{array}$ \\
\hline Stern (1995) & $\begin{array}{l}\text { Screening rules with } \\
\text { ADL and IADL } \\
\text { problems }\end{array}$ & $\begin{array}{l}\text { Modes of living alone, } \\
\text { living in nursing home, } \\
\text { or being cared by a } \\
\text { child }\end{array}$ & $\begin{array}{l}\text { National Long-term } \\
\text { Care Survey }\end{array}$ & $\begin{array}{l}1982 \text { screening } \\
\text { survey, and } 1984 \\
\text { re-interview }\end{array}$ & 3,447 & $\begin{array}{l}\text { Effects of parent's } \\
\text { characteristics on long- } \\
\text { term care decision, not } \\
\text { child characteristics }\end{array}$ \\
\hline Ettner (1994) & $\begin{array}{l}\text { Aged } 65+, \text { ADL, IADL } \\
\text { and Medicaid }\end{array}$ & $\begin{array}{l}\text { Discrete choice of } \\
\text { nursing home entry } \\
\text { and home care } \\
\text { demand }\end{array}$ & $\begin{array}{l}\text { National Long-term } \\
\text { Care Survey }\end{array}$ & 1982 and 1984 & $\begin{array}{l}442 \text { nursing home; } \\
4,295 \text { home care }\end{array}$ & $\begin{array}{l}\text { Effect of Medicaid home } \\
\text { care subsidies on } \\
\text { nursing home care }\end{array}$ \\
\hline
\end{tabular}




\begin{tabular}{|c|c|c|c|c|c|c|}
\hline Authors & Setting & Design and Method & Data Sources & Time Horizon & Sample Size & Major Findings \\
\hline Kemper (1992) & $\begin{array}{l}\text { Disabled and unmet } \\
\text { need elderly who meet } \\
\text { Channeling eligibility } \\
\text { criteria }\end{array}$ & $\begin{array}{l}\text { Telephone and in } \\
\text { person interview }\end{array}$ & $\begin{array}{l}\text { Channeling } \\
\text { experiment }\end{array}$ & $1982-1983$ & 5,150 & $\begin{array}{l}\text { Use, cost, and financing } \\
\text { of home care by } \\
\text { applicants to the } \\
\text { Channeling program }\end{array}$ \\
\hline $\begin{array}{l}\text { Swan and } \\
\text { Benjamin (1990) }\end{array}$ & $\begin{array}{l}\text { Aged } 85+, \text { Medicare } \\
\text { home health care } \\
\text { utilization }\end{array}$ & $\begin{array}{l}\text { Demand and supply } \\
\text { factors }\end{array}$ & $\begin{array}{l}\text { Medicare and } \\
\text { Medicaid; Institute } \\
\text { for Health and } \\
\text { Aging }\end{array}$ & 1978-1984 & 41 states & $\begin{array}{l}\text { State variation in } \\
\text { Medicare and Medicaid } \\
\text { home health care use }\end{array}$ \\
\hline $\begin{array}{l}\text { Moscovice et al. } \\
(1988)\end{array}$ & $\begin{array}{l}\text { Elderly of risk of } \\
\text { nursing home placement } \\
\text { in Minnesota in the US }\end{array}$ & $\begin{array}{l}\text { Client placement, } \\
\text { functional status, } \\
\text { informal and formal } \\
\text { care, and caregiver } \\
\text { factors }\end{array}$ & $\begin{array}{l}\text { A screening tool of } \\
\text { the Health and } \\
\text { psychological needs; } \\
\text { Medicare and } \\
\text { Medicaid }\end{array}$ & 1984 & 214 & $\begin{array}{l}\text { Care giver allocation } \\
\text { behaviors to clients' } \\
\text { needs }\end{array}$ \\
\hline Greene (1983) & $\begin{array}{l}\text { Impaired elderly aged } \\
60+\text { living in the } \\
\text { community }\end{array}$ & $\begin{array}{l}\text { Sub-sample of } \\
\text { statewide survey, long- } \\
\text { term care, various } \\
\text { settings }\end{array}$ & $\begin{array}{l}\text { Random sample of } \\
\text { the Community } \\
\text { Service System (CSS) }\end{array}$ & 1980 & 682 & $\begin{array}{l}\text { Use and allocation } \\
\text { behaviors of formal and } \\
\text { informal care providers }\end{array}$ \\
\hline \multicolumn{7}{|l|}{ Nursing home care } \\
\hline $\begin{array}{l}\text { Grabowski and } \\
\text { Gruber (2005) }\end{array}$ & $\begin{array}{l}\text { Community - dwelling } \\
\text { and institutionalized } \\
\text { elderly }\end{array}$ & $\begin{array}{l}\text { Exclusion of } \\
\text { Medicare-financed } \\
\text { nursing home stay, } \\
\text { spend-down policy }\end{array}$ & $\begin{array}{l}\text { National Long-Term } \\
\text { Care Survey }\end{array}$ & $\begin{array}{l}1984,1989,1994 \text { and } \\
1999\end{array}$ & 25,697 & $\begin{array}{l}\text { No effect of Medicaid } \\
\text { policy on nursing home } \\
\text { utilization }\end{array}$ \\
\hline Puts et al. (2005) & $\begin{array}{l}\text { Adults aged } 65+ \\
\text { Netherlands }\end{array}$ & $\begin{array}{l}\text { Nursing home } \\
\text { admission } \\
\text { Static frailty and } \\
\text { dynamic frailty by } \\
\text { nine frailty markers }\end{array}$ & $\begin{array}{l}\text { Longitudinal Aging } \\
\text { Study Amsterdam } \\
\text { (LASA) }\end{array}$ & $\begin{array}{l}1992-1993 \text { and } \\
1995-1996\end{array}$ & 1,503 & $\begin{array}{l}\text { Significant relationship } \\
\text { between static and } \\
\text { dynamic frailties, and } \\
\text { institutionalization }\end{array}$ \\
\hline $\begin{array}{l}\text { Gaugler et al. } \\
(2004)\end{array}$ & $\begin{array}{l}\text { Pre- and post- } \\
\text { institutionalization for } 4 \\
\text { years }\end{array}$ & $\begin{array}{l}\text { Primary objective and } \\
\text { subjective stressors } \\
\text { and context of care }\end{array}$ & $\begin{array}{l}\text { Caregiver Stress and } \\
\text { Coping Study } \\
\text { (Aneshensel et al., } \\
\text { 1995) }\end{array}$ & $\begin{array}{l}\text { Article does not state } \\
\text { the year of sampling }\end{array}$ & 185 caregivers & $\begin{array}{l}\text { Negative association } \\
\text { between visiting and role } \\
\text { of post- } \\
\text { institutionalization }\end{array}$ \\
\hline
\end{tabular}




\begin{tabular}{|c|c|c|c|c|c|c|}
\hline Authors & Setting & Design and Method & Data Sources & Time Horizon & Sample Size & Major Findings \\
\hline $\begin{array}{l}\text { Lakdawalla and } \\
\text { Schoeni (2003) }\end{array}$ & $\begin{array}{l}\text { Spousal age gap and } \\
\text { nursing home use }\end{array}$ & $\begin{array}{l}\text { Demand for nursing } \\
\text { home care simulation }\end{array}$ & $\begin{array}{l}\text { Medicare Current } \\
\text { Beneficiary Surveys }\end{array}$ & $1992-1996$ & $9,823-10,554$ & $\begin{array}{l}\text { Shrinking age gap with } \\
\text { women's less nursing } \\
\text { entry and less spending }\end{array}$ \\
\hline $\begin{array}{l}\text { Lakdawalla and } \\
\text { Philipson (1999) }\end{array}$ & $\begin{array}{l}\text { Number of males and } \\
\text { females in county and } \\
\text { long-term care facilities }\end{array}$ & $\begin{array}{l}\text { Demand for nursing } \\
\text { home care }\end{array}$ & $\begin{array}{l}\text { National Master } \\
\text { Facility Inventory; } \\
\text { the census data }\end{array}$ & $\begin{array}{l}\text { 1971,1973, } \\
1976,1978, \\
1980,1982,1986 \text {, and } \\
1991\end{array}$ & $\begin{array}{l}9,155 \text { aged } 65+\& \\
9,154 \text { aged } 75+\end{array}$ & $\begin{array}{l}\text { Decrease in nursing } \\
\text { home entrance by } \\
\text { spouse presence, but not } \\
\text { children }\end{array}$ \\
\hline Bauer (1996) & $\begin{array}{l}\text { Clients initially in home } \\
\text { \& community based care } \\
\text { before NHC }\end{array}$ & $\begin{array}{l}\text { Hazard of nursing } \\
\text { home entry (NHCE) }\end{array}$ & $\begin{array}{l}\text { Arizona Long- Term } \\
\text { Care System }\end{array}$ & $\begin{array}{l}\text { January } 1989- \\
\text { December } 1991\end{array}$ & 2,923 & $\begin{array}{l}\text { Risk of NHCE with } \\
\text { ageing, white, male and } \\
\text { Alzheimer }\end{array}$ \\
\hline $\begin{array}{l}\text { Greene et al. } \\
\text { (1993) }\end{array}$ & $\begin{array}{l}\text { Transition from the } \\
\text { community to nursing } \\
\text { home aged } 65+\end{array}$ & $\begin{array}{l}\text { Three alternative } \\
\text { transition measures }\end{array}$ & $\begin{array}{l}\text { National Long } \\
\text { Term-Care } \\
\text { Demonstration }\end{array}$ & $1982-1985$ & 3,017 & $\begin{array}{l}\text { Nursing service with } \\
\text { wheelchair and home } \\
\text { help with cognitive } \\
\text { impairment }\end{array}$ \\
\hline \multicolumn{7}{|c|}{ Cost of long-term care } \\
\hline $\begin{array}{l}\text { Coughlin et al. } \\
\text { (1992) }\end{array}$ & $\begin{array}{l}\text { Paid home care visits } \\
\text { aged } 75+\text {, skilled and } \\
\text { non-skilled }\end{array}$ & $\begin{array}{l}\text { Home care use under } \\
\text { public program and } \\
\text { cost simulation }\end{array}$ & $\begin{array}{l}\text { the } 1982 \text { National } \\
\text { Long-Term Care } \\
\text { Survey }\end{array}$ & 1982 & 4,699 & $\begin{array}{l}\$ 1.8-\$ 2.7 \text { billion } \\
\text { expected publicly } \\
\text { funded home care cost }\end{array}$ \\
\hline \multicolumn{7}{|c|}{ Quality of nursing home care } \\
\hline $\begin{array}{l}\text { Grabowski et al. } \\
(2004)\end{array}$ & $\begin{array}{l}\text { Nursing home facilities } \\
\text { in the US }\end{array}$ & $\begin{array}{l}\text { Quality and Medicaid } \\
\text { reimbursement }\end{array}$ & $\begin{array}{l}\text { The On-Line Survey, } \\
\text { Certification, and } \\
\text { Reporting system } \\
\text { (OSCAR) }\end{array}$ & $\begin{array}{l}\text { October } 1998- \\
\text { December } 1999\end{array}$ & 15,128 & $\begin{array}{l}\text { Higher reimbursement } \\
\text { vs. lower incidence of } \\
\text { pressure ulcers and } \\
\text { physical restraints }\end{array}$ \\
\hline Mor et al. (2004) & $\begin{array}{l}\text { Nursing home facilities } \\
\text { in the US }\end{array}$ & $\begin{array}{l}\text { The upper and lower } \\
\text { tires of the nursing } \\
\text { home structure }\end{array}$ & $\begin{array}{l}\text { Medicare- Medicaid- } \\
\text { certified nursing } \\
\text { facilities, OSCAR, } \\
\text { and MDS }\end{array}$ & 2000 & $\begin{array}{l}17,000 \text { nursing } \\
\text { facilities }\end{array}$ & $\begin{array}{l}\text { Proprietary and non- } \\
\text { chain affiliated nursing } \\
\text { home facilities } \\
\text { dominated by Medicaid } \\
\text { residents }\end{array}$ \\
\hline $\begin{array}{l}\text { Grabowski } \\
(2001)\end{array}$ & $\begin{array}{l}\text { Nursing home facilities } \\
\text { in the US }\end{array}$ & $\begin{array}{l}\text { Nursing home quality } \\
\text { and Medicaid rate }\end{array}$ & $\begin{array}{l}\text { MMACS, OSCAR, } \\
\text { and NY }\end{array}$ & 1981, and 1995-1996 & $\begin{array}{l}\text { MMACS }(13,346) ; \\
\text { OSCAR }(15,463) ; \\
\text { and NY }(579)\end{array}$ & $\begin{array}{l}\text { Medicaid rate vs. input } \\
\text { quality (positive); } \\
\text { negative association } \\
\text { with pressure score }\end{array}$ \\
\hline
\end{tabular}


Formal and informal home care

Nishiwaki et al. Elderly people living at ADL, MMSE Primary survey in (cognitive impairment) Niigata Prefecture

January-April 2003194 elderly

Negative between ADL and GDS-15

(depressed mood scale)

Sato et al. (2006) Low income beneficiaries

Arai (2004)

Disabled elderly and

tilization of home

help service by crosssectional survey

Five municipal

October-November

37 subsidized, 124 and GDS-15 score

Zarit Burden

insurers Ka

caregivers

Primary survey:

non-subsidized

Greater utilization by subsidized beneficiaries Interview (ZBI) Matsuyama Town

October 1998-

ADL, behavioral burden, cognitive

Primary survey: clinic/hospital impairment, and related patients in severity of dementia Kyoto

Ohkusa (2000) Households with a person aged $65+$

Survey of Public

July 1999

The article does not No significant difference explicitly show the of mean of ZBI before sample size 2000 and after

46 pairs of impaired Behavior disturbance as elderly and their a strong caregivers' caregivers

burden survey of a choice of Long-term Care care services, meals, Insurance

and nurse visits

Iwamoto (2000) National informal home Longitudinal care participation for

Comprehensive

1992, 19951998

481

Elastic demand curves for meal services and nurse visits

2,096 care receivers; Female with low 291 care receivers; opportunity costs Conditions of People on Health and

Welfare

Liu et al. (1995) Elderly Japanese aged Longitudinal

Two-wave national

probability sample

Patterns, determinants of transition in

functional status among elderly 


\begin{tabular}{|c|c|c|c|c|c|c|}
\hline Authors & Setting & Design and Method & Data Sources & Time Horizon & Sample Size & Major Findings \\
\hline \multicolumn{7}{|l|}{ Nursing home care } \\
\hline Oura et al. (2006) & $\begin{array}{l}\text { Frail elderly receiving } \\
\text { home care and their } \\
\text { caregivers }\end{array}$ & $\begin{array}{l}\text { Risk of } \\
\text { institutionalization }\end{array}$ & $\begin{array}{l}\text { Primary survey: } \\
\text { elderly receiving } \\
\text { home care in Kyushu }\end{array}$ & $1998-2003$ & $\begin{array}{l}52 \text { males, } 70 \text { females } \\
\text { and their caregivers }\end{array}$ & $\begin{array}{l}\text { Depressive caregivers } \\
\text { with institutionalization } \\
\text { of frail elderly }\end{array}$ \\
\hline $\begin{array}{l}\text { Kurimori et al. } \\
\text { (2006) }\end{array}$ & $\begin{array}{l}\text { Long-term care } \\
\text { insurance service } \\
\text { providers }\end{array}$ & $\begin{array}{l}\text { Disability adjusted life } \\
\text { expectancy (DALE) }\end{array}$ & $\begin{array}{l}\text { Primary survey: in } \\
\text { Tokyo } 236 \\
\text { professionals; } 11 \\
\text { long-term care } \\
\text { insurance service } \\
\text { providers }\end{array}$ & $\begin{array}{l}\text { October-November } \\
2003\end{array}$ & $\begin{array}{l}202 \text { women and } 22 \\
\text { men }\end{array}$ & $\begin{array}{l}\text { Strong correlations } \\
\text { between DALE and } \\
\text { mortality for both sex }\end{array}$ \\
\hline $\begin{array}{l}\text { Chuma et al. } \\
\text { (1994) }\end{array}$ & Aged $70+$ & $\begin{array}{l}\text { Demand for long-term } \\
\text { care }\end{array}$ & $\begin{array}{l}\text { Prefecture data: } \\
\text { Health Insurance for } \\
\text { the Aged (MHW) }\end{array}$ & 1986, 1989 and 1992 & $\begin{array}{l}3,443 \text { home } 133 \\
\text { social welfare } \\
\text { institutions } 2,027 \\
\text { hospitals }\end{array}$ & $\begin{array}{l}\text { Strong negative } \\
\text { correlation between } \\
\text { home care and hospital } \\
\text { care }\end{array}$ \\
\hline $\begin{array}{l}\text { Ogura and Oishi } \\
\text { (1994) }\end{array}$ & $\begin{array}{l}\text { Patients aged } 65+\text { in } \\
\text { geriatric hospitals }\end{array}$ & $\begin{array}{l}\text { Cross-sectional in } \\
\text { Tokyo and Hokkaido }\end{array}$ & $\begin{array}{l}\text { Survey of long-term } \\
\text { care by Ikegami } \\
\text { Data Set }\end{array}$ & 1992 & 977 & $\begin{array}{l}\text { Fixed fee and decrease } \\
\text { in input-mix and } \\
\text { medication }\end{array}$ \\
\hline \multicolumn{7}{|l|}{$\begin{array}{l}\text { Cost of long- } \\
\text { term care }\end{array}$} \\
\hline Kimura (1996) & $\begin{array}{l}\text { National macro-level, } \\
\text { aged } 65+\text {, bed ridden or } \\
\text { dementia }\end{array}$ & Simulation Perspective & $\begin{array}{l}\text { Japanese Welfare } \\
\text { White Paper (1989) } \\
\text { and Elderly Home } \\
\text { Care (1993) }\end{array}$ & $2000-2010$ & $\begin{array}{l}\text { Yearly aggregate } \\
\text { data from 1970-1993 }\end{array}$ & $\begin{array}{l}\text { Cost estimation of long- } \\
\text { term care }\end{array}$ \\
\hline \multicolumn{7}{|c|}{ Quality of nursing home care } \\
\hline $\begin{array}{l}\text { Horiguchi et al. } \\
(2004)\end{array}$ & $\begin{array}{l}\text { Staff at long-term care } \\
\text { facilities }\end{array}$ & $\begin{array}{l}\text { Human resources and } \\
\text { patients with nine } \\
\text { specific conditions }\end{array}$ & $\begin{array}{l}\text { Survey for health } \\
\text { service facilities and } \\
\text { special nursing } \\
\text { homes in Kyushu }\end{array}$ & February 2001 & $\begin{array}{l}300 \text { health service } \\
\text { facilities } 419 \text { special } \\
\text { nursing homes }\end{array}$ & $\begin{array}{l}\text { Discrepancies between } \\
\text { system goals and current } \\
\text { activities }\end{array}$ \\
\hline $\begin{array}{l}\text { Ikegami et al. } \\
\text { (1994) }\end{array}$ & $\begin{array}{l}\text { Residents in long-term } \\
\text { care facilities }\end{array}$ & $\begin{array}{l}\text { Resource Utilization } \\
\text { Group, Version III }\end{array}$ & $\begin{array}{l}\text { Primary survey: } \\
\text { long-term care } \\
\text { facilities and } \\
\text { hospitals in Tokyo }\end{array}$ & $\begin{array}{l}\text { October-December } \\
1991\end{array}$ & 871 & $\begin{array}{l}\text { Wide discrepancy } \\
\text { between purpose of } \\
\text { facilities and patient } \\
\text { characteristics }\end{array}$ \\
\hline
\end{tabular}


632

\section{About the Authors}

Tetsuji Yamada, Ph.D., is a Professor of Health Economics with the Department of Economics at Rutgers University, the State University of New Jersey, U.S.A. His specializations are: health behavior and health education, health care finance, costbenefit analysis and pharmaceutical economics. His current research includes studies on cancer screening behavior, patients with dyslipidemia, hospital cost analysis, pharmaceutical innovation and health outcomes, health care services, elderly care, preventive care, and health insurance and health outcomes.

Chia-Ching Chen, M.A. \& M.S., is a doctoral candidate in Health and Behavior Studies at the Teachers College, Columbia University. Her specialization includes: behavioral analysis of public health, social influence and communication, health education and health promotion, and environmental health. She has had previous professional experience from the EPA and the Institute of Economics at the Academia Sinica in Taiwan, and was a research member of the Pfizer Health Project at the University of Tsukuba, Japan.

Tadashi Yamada, Ph.D., is a Professor of Economics with the Graduate School of Humanities and Social Sciences at the University of Tsukuba, Japan. He is one of the leading health economists in Japan. His main interest is health economics and applied microeconomics. His works have been published in respected professional journals, such as the Journal of Human Resources, Health Economics, Applied Economics, and Social Science \& Medicine, and books by the National Bureau of Economic Research. Marianne Fahs, Ph.D. \& MPH, is a Professor of the Graduate Program for Urban Public Health, and Director of the Brookdale Center on Aging of Hunter College, School of Health Sciences at Hunter College, City University of New York. She is the author of over 100 articles and reports in health services research literature, including empirical analyses and methodological appraisals of cost-effectiveness analysis of preventive services for the elderly.

Tetsuo Fukawa, Ph.D., is Head of the Department of Social Security Research I, National Institute of Population and Social Security Research, Minister of Health, Labor and Welfare of Japan. His main areas of research are health services study, social security finance, and social policy on the elderly. He has been publishing his research work in the field of ageing and health care policy actively. 